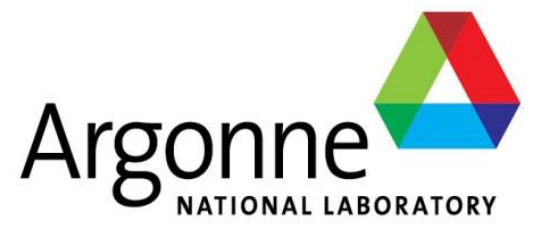

ANL/ESD-14/12 Rev.

\title{
Development of GREET Catalyst Module
}

\author{
Energy Systems Division
}




\begin{abstract}
About Argonne National Laboratory
Argonne is a U.S. Department of Energy laboratory managed by UChicago Argonne, LLC under contract DE-AC02-06CH11357. The Laboratory's main facility is outside Chicago, at 9700 South Cass Avenue, Argonne, Illinois 60439. For information about Argonne and its pioneering science and technology programs, see www.anl.gov.
\end{abstract}

\title{
DOCUMENT AVAILABILITY
}

Online Access: U.S. Department of Energy (DOE) reports produced after 1991 and a growing number of pre-1991 documents are available free via DOE's SciTech Connect (http://www.osti.gov/scitech/).

Reports not in digital format may be purchased by the public from the National Technical Information Service (NTIS):

U.S. Department of Commerce

National Technical Information Service

5301 Shawnee Road

Alexandria, VA 22312

www.ntis.gov

Phone: (800) 553-NTIS (6847) or (703) 605-6000

Fax: (703) 605-6900

Email: orders@ntis.gov

Reports not in digital format are available to DOE and DOE contractors from the Office of Scientific and Technical Information (OSTI):

U.S. Department of Energy

Office of Scientific and Technical Information

P.O. Box 62

Oak Ridge, TN 37831-0062

www.osti.gov

Phone: (865) 576-8401

Fax: (865) 576-5728

Email: reports@osti.gov

\section{Disclaimer}

This report was prepared as an account of work sponsored by an agency of the United States Government. Neither the United States Government nor any agency thereof, nor UChicago Argonne, LLC, nor any of their employees or officers, makes any warranty, express or implied, or assumes any legal liability or responsibility for the accuracy, completeness, or usefulness of any information, apparatus, product, or process disclosed, or represents that its use would not infringe privately owned rights. Reference herein to any specific commercial product, process, or service by trade name, trademark, manufacturer, or otherwise, does not necessarily constitute or imply its endorsement, recommendation, or favoring by the United States Government or any agency thereof. The views and opinions of document authors expressed herein do not necessarily state or reflect those of the United States Government or any agency thereof. 
ANL/ESD-14/12 Rev.

\section{Development of GREET Catalyst Module}

by

Zhichao Wang, Pahola T. Benavides, Jennifer B. Dunn, and Donald C. Cronauer

Energy Systems Division, Argonne National Laboratory

September 2015 



\section{CONTENTS}

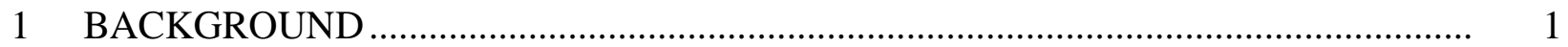

2 CATALYSTS WITH A $\gamma$-ALUMINA SUPPORT …………………………............... 2

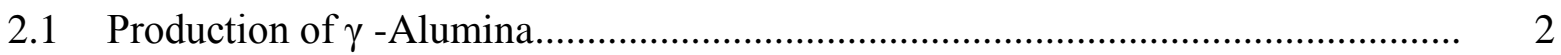

$2.2 \mathrm{Mo} / \mathrm{Co}$ on $\gamma$ Alumina ....................................................................................

2.2.1 Treatment of Spent Catalyst...................................................................... 6

2.2.1.1 Recovered Spent Catalyst Treatment from

Petroleum Refineries.............................................................. 8

2.2.1.2 Recovered Spent Catalyst Treatment from

Bioprocessing Refineries ......................................................... 10

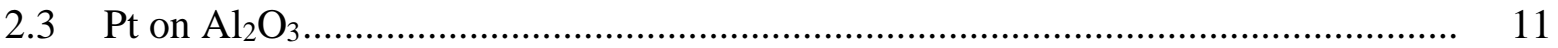

$2.4 \quad$ Tar Reforming Catalyst.................................................................................... 14

3 CHEMICALS FOR INDIRECT GASIFICATION AND MIXED ALCOHOL

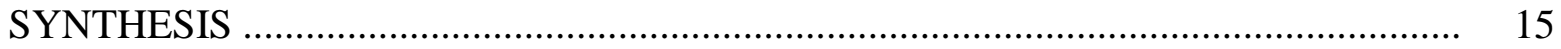

3.1 Olivine

3.2 DEPG ………............................................................................ 16

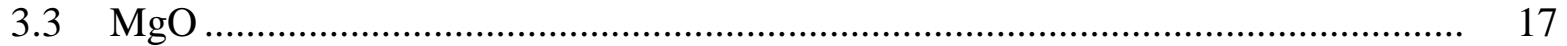

3.4 Alcohol Synthesis Catalyst .............................................................................. 17

3.4.1 Activated Carbon ......................................................................... 18

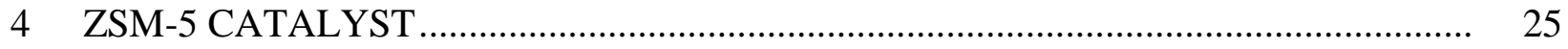

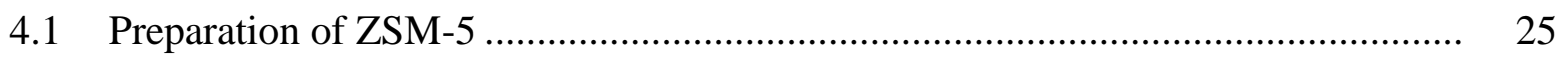

4.2 Preparation of Fillers and Binders …………….................................................... 29

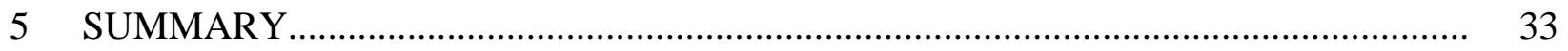

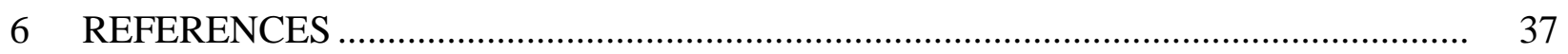

\section{FIGURES}

$1 \quad$ Production of $\gamma$-alumina from crude alumina .................................................................. 4

2 Impregnation of alumina-supported catalyst ……….............................................. 6

3 GCMC spent catalyst treatment process .................................................................. 9

$4 \quad$ General scheme of activated carbon production from coal ........................................ 19 


\section{FIGURES (CONT.)}

$5 \quad$ Diagram for preparation of ZSM-5 catalyst .............................................................. 26

$6 \quad$ Diagram for production of kaolin ..................................................................... 30

7 Cradle-to-gate GHG emissions for ZSM-5 catalyst; emissions from ZSM-5 are broken up into five contributing factors .................................................................. 34

8 Cradle-to-gate GHG emissions for $\mathrm{Mo} / \mathrm{Co} / \mathrm{\gamma}$-Alumina catalyst ..................................... 35

9 Cradle-to-gate GHG emissions for Pt/ $\mathrm{y}$-Alumina catalyst .......................................... 35

10 Sensitivity analysis of ZSM-5 catalyst cradle-to-gate GHG emissions; baseline value is $7.7 \mathrm{~kg} \mathrm{CO} 2 \mathrm{e} / \mathrm{kg} \mathrm{ZSM}-5$ catalyst................................................................. 36

\section{TABLES}

1 Material and energy consumption in the conversion of crude alumina to $\gamma$-alumina...... 4

2 Material and energy consumption in the production of the $\mathrm{Mo} / \mathrm{Co} / \mathrm{y}-\mathrm{Al}_{2} \mathrm{O}_{3}$ catalyst .... 6

3 Composition of typical spent catalysts ...................................................................... 8

$4 \quad$ Material and energy consumption in treatment of spent catalysts used in the conversion of petrochemical feedstocks ................................................................. 10

$5 \quad$ Material and energy consumption in the production of the $\mathrm{Pt} / \mathrm{\gamma}-\mathrm{Al}_{2} \mathrm{O}_{3}$ catalyst ............ 12

$6 \quad$ Material and energy consumption associated with the aqua regia spent catalyst process

$7 \quad$ Material and energy consumption associated with the pyrometallurgical

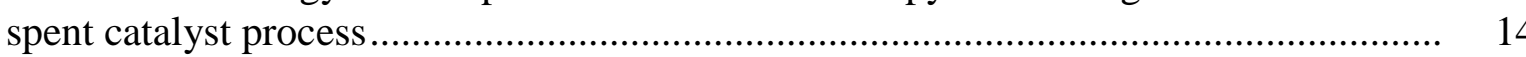

$8 \quad$ Energy consumption for metal mining (GREET2) ................................................ 16

$9 \quad$ Purchased energy inputs to olivine production.............................................................. 16

10 Equipment used during raw material handling and preparation to produce activated carbon 


\section{TABLES (CONT.)}

11 Purchased energy inputs for material handling and coal preparation.......................... 21

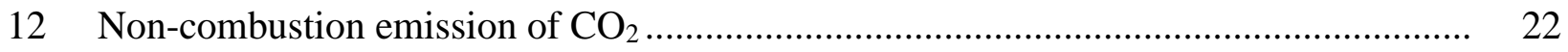

$13 \mathrm{PM}_{10}$ non-combustion emissions .................................................................... 22

14 Carbonization, activation, and process heating equipment and energy inputs .............. 24

15 Inputs and outputs for the production of $600 \mathrm{lb} /$ day ZSM-5 .................................. 26

16 Energy consumption during ZSM-5 preparation ................................................. 27

17 Material inputs for TPAOH production ........................................................... 29

18 Energy consumption during kaolin production ............................................... 31

19 Materials inputs for kaolin production............................................................ 31

20 Fossil fuel use and GHG emissions of the compounds in the GREET catalyst module 
This page intentionally left blank. 


\title{
DEVELOPMENT OF GREET CATALYST MODULE
}

\author{
Zhichao Wang, Pahola T. Benavides, Jennifer B. Dunn, Donald C. Cronauer
}

\section{BACKGROUND}

Catalysts are critical inputs for many pathways that convert biomass into biofuels. Energy consumption and greenhouse gas (GHG) emissions during the production of catalysts and chemical inputs influence life-cycle energy consumption, and GHG emissions of biofuels and need to be considered in biofuel life-cycle analysis (LCA).

In this report, we develop energy and material flows for the production of five different catalysts (tar reforming, alcohol synthesis, Zeolite Socony Mobil-5 [ZSM-5], Mo/Co/ $\gamma-\mathrm{Al}_{2} \mathrm{O}_{3}$, and $\mathrm{Pt} / \mathrm{\gamma}-\mathrm{Al}_{2} \mathrm{O}_{3}$ ) and two chemicals (olivine, dimethyl ether of polyethylene glycol [DEPG]). These compounds and catalysts are now included in the Greenhouse Gases, Regulated Emissions and Energy Use in Transportation (GREET ${ }^{\mathrm{TM}}$ ) catalyst module. They were selected for a number of reasons. A primary reason is that some of these compounds are consumed in existing U.S. Department of Energy (DOE) analyses of biofuel processes. For example, a thermochemical ethanol production pathway (indirect gasification and mixed alcohol synthesis) developed by the National Renewable Energy Laboratory (NREL) uses olivine, DEPG, and tar reforming and alcohol synthesis catalysts (Dutta et al., 2011). ZSM-5 can be used in biofuel production pathways such as catalytic upgrading of sugars into hydrocarbons (Biddy and Jones, 2013). Other compounds are expected to be used in aqueous phase reforming or lignin upgrading (Alonso et al. 2012). Other uses for these compounds and catalysts are certainly possible.

In this report, we document the data sources and methodology we used to develop material and energy flows for the catalysts and compounds in the GREET catalyst module. This module estimates energy and water consumption and air emissions, including GHG emissions of catalysts from cradle-to-gate. In Section 2 we focus on catalysts built on a $\gamma$-alumina support, including a tar reforming catalyst, $\mathrm{Mo} / \mathrm{Co} / \mathrm{\gamma}-\mathrm{Al}_{2} \mathrm{O}_{3}$ and $\mathrm{Pt} / \mathrm{\gamma}-\mathrm{Al}_{2} \mathrm{O}_{3}$. In Section 3, we describe the production of compounds and catalysts used in the indirect gasification design case developed by Dutta et al. (2011). In Section 4, we report material and energy flows associated with ZSM-5 production. Finally, in Section 5, we report results and information regarding the structure and use of the GREET catalysis module, including the addition of an option for a user-defined catalyst. 


\section{CATALYSTS WITH A $\gamma$-ALUMINA SUPPORT}

The GREET catalyst module contains three catalysts with a $\gamma-\mathrm{Al}_{2} \mathrm{O}_{3}$ support. In this section of the report, we first describe the production of the $\gamma$-alumina support (Section 2.1). We then describe each of the catalysts included in the module that use this support. The first is $\mathrm{Mo} / \mathrm{Co}$ on $\gamma-\mathrm{Al}_{2} \mathrm{O}_{3}$ (Section 2.2), which can be used in lignin conversion and in other transformations (Alonso et al. 2012). The second is $\mathrm{Pt}$ on $\gamma-\mathrm{Al}_{2} \mathrm{O}_{3}$ (Section 2.3), which can be used in aqueous phase reforming (Alonso et al. 2012). Certainly, $\mathrm{Pt}$ is an important catalytic metal overall and its inclusion in the catalyst module allows users to incorporate it into a userdefined catalyst option within the module. For these first two catalyst types, we describe how they could be processed when they are spent. Again, these metals, along with the $\mathrm{Al}_{2} \mathrm{O}_{3}$ support, can be combined in different ratios and assigned an energy and material intensity of production in the catalyst module user-defined option, which provides GREET users flexibility in developing the energy and GHG intensity of catalysts of interest. The third catalyst with a $\gamma$ alumina support is a tar reforming catalyst used in the indirect gasification process, for which the other inputs are the focus of Section 3. The tar reforming catalyst (Section 2.4) is made up of nickel oxide $(\mathrm{NiO})$, potassium oxide $\left(\mathrm{K}_{2} \mathrm{O}\right)$, and magnesium oxide $(\mathrm{MgO})$ on a $\gamma$-alumina support. In this and subsequent sections, we describe net water consumption of the processes to produce catalysts. It is important to note that we define water consumption as the quantity of water that is fed to a process less water that can be recovered from the process at a sufficient level of quality such that it can be returned to a water source (e.g., a river or aquifer). Given that we often have limited information about these processes, we often assume that the waste water a process produces can be sent to a waste water treatment plant, which has an $80 \%$ water treatment efficiency. The actual efficiency will depend on the level and type of contamination in the water but the $80 \%$ assumption was adopted as a somewhat conservative value.

\subsection{PRODUCTION OF $\gamma$-ALUMINA}

We assume that crude alumina must undergo a purification step to yield $\gamma$-alumina. There are a number of producers of catalytic alumina supports; a shortened list includes Albemarle, ASM Catalysts, Criterion (Shell Oil), Haldor-Topsoe, Johnson Matthey, Riogen, Saint-Gobain, UOP Honeywell Co., W.R. Grace \& Co., and Alibaba (China). Each supplier likely has their own proprietary process to produce activated alumina to serve as a catalyst support. The refining of bulk alumina from bauxite is discussed elsewhere (Dai et al., 2015).

One resource (Reactor Resources 2013) describes the production of activated alumina as commencing with bauxite mining. The bauxite is subsequently refined in the Bayer process that uses $\mathrm{NaOH}$ to remove impurities. The product of the Bayer process is aluminum trihydrate or "hydrate." Annually, approximately 100 million tons of aluminum trihydrate are manufactured, with $10 \%$ of this product used in the adsorbent and catalyst market.

A UOP patent (Mitsche et al. 1978) indicates that the alumina is prepared through the mixing of an alpha-alumina monohydrate with an alkaline solution of $\mathrm{pH}$ about 7.5 to form a 
stable suspension. To this suspension is added a salt of a strong acid, forming a dough-like substance that is subsequently formed into extrudates, dried, and calcined.

A number of additional approaches can be used to prepare an effective alumina catalyst support. First, the raw alumina can be digested in either caustic or acidic solutions. Secondly, alumina can be precipitated from either solution or from a mixture of these solutions. The crystalline form of the resulting precipitate is modified by a combination of seeding, temperature programming, diffusion (mixing), and aging. There are at least seven crystal forms of alumina, of which the $Y-\mathrm{Al}_{2} \mathrm{O}_{3}$ and $\eta-\mathrm{Al}_{2} \mathrm{O}_{3}$ are of greatest interest for catalysis. In addition, these crystal forms have various "metal atom gaps" that promote interaction with catalytic metals deposited on the surface. $\Upsilon-\mathrm{Al}_{2} \mathrm{O}_{3}$ is typically chosen because it is of high surface area and reasonable stability. Specific details are discussed by Satterfield (1991).

A block flow diagram for the production of $\Upsilon-\mathrm{Al}_{2} \mathrm{O}_{3}$ from a combination of these options is shown in Figure 1. It is also assumed that the feed consists of bulk $\alpha-\mathrm{Al}_{2} \mathrm{O}_{3}$ generated from the refining of bauxite. Note that $\mathrm{NaAlO}_{2}$ can be obtained from the bauxite/alumina producer. In this case, the process would avoid energy expended in the crushing and sizing and caustic digestion steps. Herein, we consider only the case that the process input is crude alumina and include a caustic digestion process, along with a subsequent acid neutralization step. The blending, aging, and curing times are estimated to be a nominal $1 \mathrm{hr}$. at $50^{\circ}$ to $75^{\circ} \mathrm{C}$. The resulting precipitate is washed with excess water $(2: 1)$ to remove salts. The filter cake is dried at about $120^{\circ} \mathrm{C}$ and subsequently calcined at about $550^{\circ} \mathrm{C}$ for a period of up to two hours. As noted above, this process configuration is only one of many available options. Material and energy intensities for this option of producing 1.0 ton of $\Upsilon-\mathrm{Al}_{2} \mathrm{O}_{3}$ are provided in Table 1. We assume here (and for other processes that we develop material and energy flows for in this report) that all necessary heat is provided as steam produced from an $80 \%$ efficient natural gas boiler. Regarding water consumption, this process consumes 103 gallons of water per ton of $\gamma-\mathrm{Al}_{2} \mathrm{O}_{3}$ during the drying and calcination steps. The balance of the water consumption reported in Table 1 stems from losses during waste water treatment. 


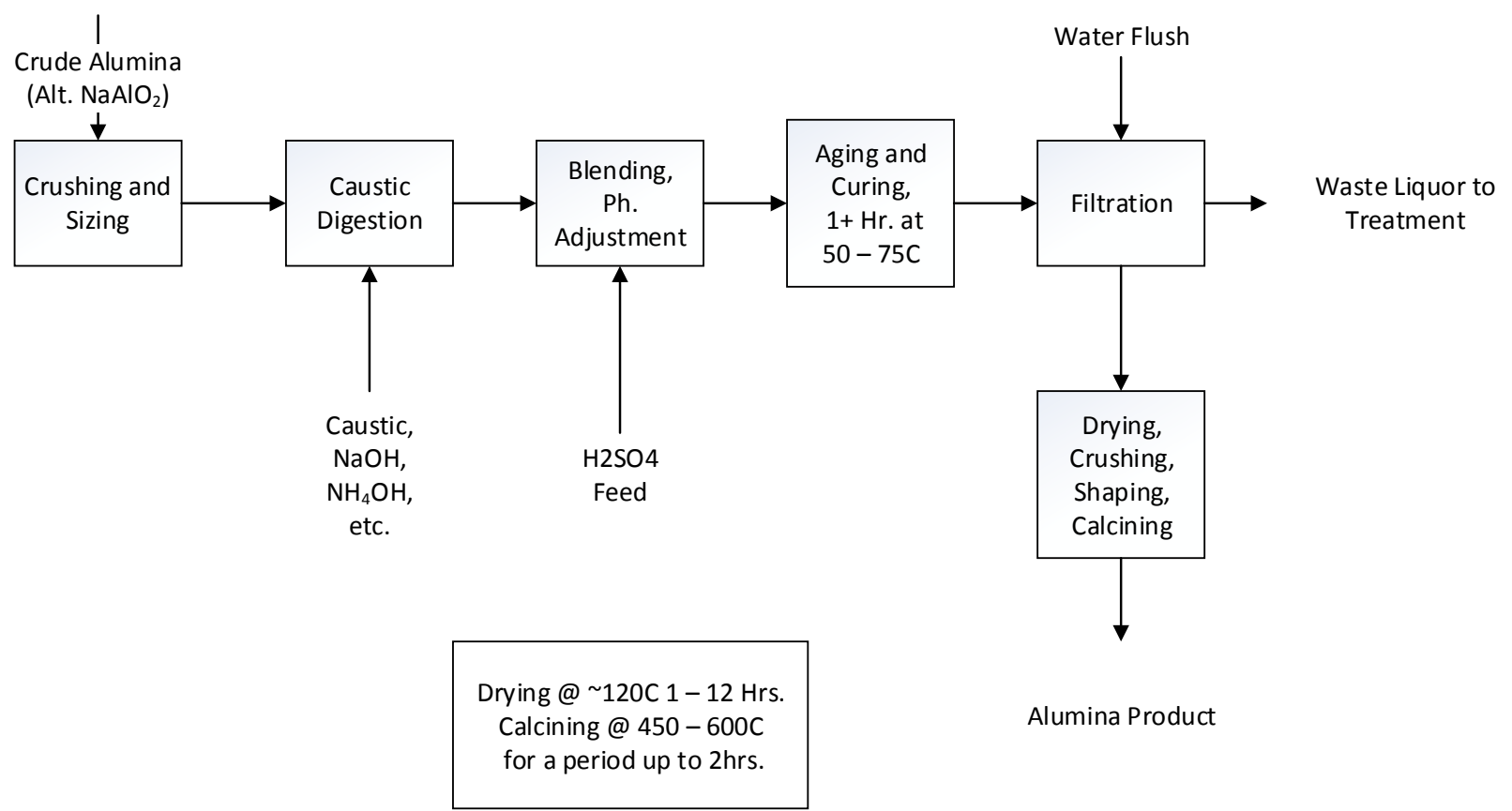

FIGURE 1 Production of $\gamma$-alumina from crude alumina

TABLE 1 Material and energy consumption in the conversion of crude alumina to $\gamma$-alumina

\begin{tabular}{|c|c|c|}
\hline Material & ton/ton Product & \\
\hline Crude alumina (99\% purity) & 1.0 & \\
\hline $\mathrm{H}_{2} \mathrm{SO}_{4}$ & 1.0 & \\
\hline $\mathrm{NaOH}$ & 0.8 & \\
\hline Water (gal/ ton product) & 514 & \\
\hline Energy & $\mathrm{mmBtu} / \mathrm{ton}$ of Product & Share $\%$ \\
\hline Natural gas & 11.5 & $98 \%$ \\
\hline Direct Elec & 0.3 & $2 \%$ \\
\hline Total Energy input & 11.8 & \\
\hline
\end{tabular}

\section{$2.2 \mathrm{Mo} / \mathrm{Co}$ on $\gamma$ ALUMINA}

The specific formulation of $\mathrm{Mo} / \mathrm{Co} / \gamma-\mathrm{Al}_{2} \mathrm{O}_{3}$ catalysts vary widely depending in part upon the desired catalyst characteristics. These catalysts can be produced from a variety of feedstocks and with several different preparation techniques. Mo (or W) can be considered the primary active metal with $\mathrm{Ni}, \mathrm{Co}$, or both, added as a promoter. Ni serves to promote hydrogenation, but its use results in increased hydrogen consumption, particularly if aromatics are present. It is also noted that the NiMo, CoMo, and NiW catalysts are used in the sulfided state to obtain and 
maintain high activity. In the event of sulfur-free feeds, $\mathrm{H}_{2} \mathrm{~S}$ or sulfur-containing compounds are added to the feed in the catalytic hydrogenation unit. In addition, the use of precious metal promoters or primary metals, such as palladium, can be used, but their activity and life are greatly influenced by sulfur levels present in the reactors. Such a discussion is not included herein.

Long et al. (1971) describe the process we assume is used for the deposition of active metals on the $\mathrm{Al}_{2} \mathrm{O}_{3}$ support. We note that we use molybdenum as the promoter, but other catalysts could well be used, such as nickel and/or cobalt. Also, a combination of these three metals could be used. Long et al. state that a preferred catalyst would include about 5 to $20 \mathrm{wt} \%$ of molybdenum, measured as $\mathrm{MoO}_{3}$. It could also include 0.5 to $4 \mathrm{wt} \% \mathrm{Co}$ and/or $\mathrm{Ni}$, measured as $\mathrm{CoO}$ and/or $\mathrm{NiO}$, respectively. The patent includes an example of a preferred composition of $3 \mathrm{wt} \% \mathrm{CoO}$ and $15 \mathrm{wt} \% \mathrm{MoO}_{3}$ and describes an impregnation technique for depositing the catalytic substances on the substrate. For example, to deposit molybdenum and cobalt, the catalyst may be impregnated with an aqueous solution of ammonium molybdate and cobalt nitrate. A calcination step at $1000^{\circ} \mathrm{F}\left(538^{\circ} \mathrm{C}\right)$ rounds out the process to yield the finished catalysts that contain a nominal composition of $3 \mathrm{wt} \%$ cobalt $(\mathrm{CoO})$ and $15 \mathrm{wt} \% \mathrm{MoO}_{3}$.

We describe the production of ammonium molybdate in a separate report (Benavides et al. 2015).

Figure 2 outlines this process in which a preformed and calcined $\Upsilon$-alumina support can be sprayed with a solution of ammonium molybdate containing sufficient water to fill the support catalyst pores, along with sufficient ammonium molybdate to provide the desired level of $\mathrm{MoO}_{3}$ after calcination. This incipient wetness impregnation (IWI) process has a nominal 0.5 hour residence time at an elevated temperature $\left(50^{\circ}\right.$ to $\left.75^{\circ} \mathrm{C}\right)$. The wetted catalyst is dried at about $120^{\circ} \mathrm{C}$ and subsequently sprayed with an IWI solution of promoter salt, such as Ni or Co nitrate. The resulting solids are dried and calcined at about $550^{\circ} \mathrm{C}$. Again, the order of deposition, the levels of the salts, the drying, calcination, and parameters of other steps vary among catalyst suppliers and users. Table 2 presents an estimation of material and energy balances for the production of one ton (2000 lbs.) of a catalyst containing $15 \mathrm{wt} \% \mathrm{MoO}_{3}$ with $3 \mathrm{wt} \% \mathrm{CoO}$ on $\gamma$ $\mathrm{Al}_{2} \mathrm{O}_{3}$. The process consumes 97 gallons of water through evaporation and calcination steps. 


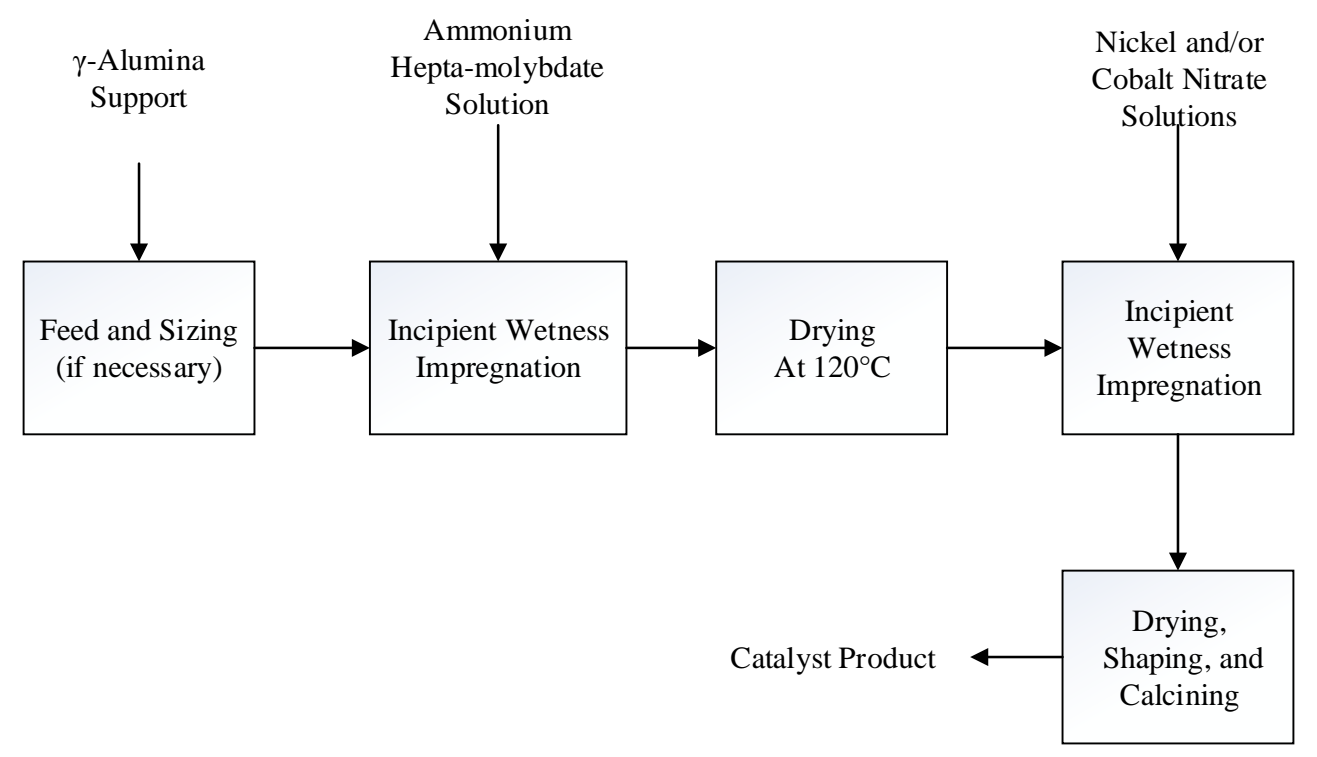

FIGURE 2 Impregnation of alumina-supported catalyst

TABLE 2 Material and energy consumption in the production of the $\mathrm{Mo} / \mathrm{Co} / \mathrm{\gamma}-\mathrm{Al}_{2} \mathrm{O}_{3}$ catalyst

\begin{tabular}{|c|c|c|}
\hline Material & ton/ton of Catalyst & \\
\hline Gamma alumina $\left(\gamma-\mathrm{Al}_{2} \mathrm{O}_{3}\right)$ & 0.8 & \\
\hline Ammonium molybdate $\left(\left(\mathrm{NH}_{4}\right)_{6} \mathrm{Mo}_{7} \mathrm{O}_{24}\right)$ & 0.3 & \\
\hline Cobalt nitrate $\left(\mathrm{Co}\left(\mathrm{NO}_{3}\right)_{2}\right)$ & 0.1 & \\
\hline Water (gal/ ton product) & 97 & \\
\hline Energy & $\mathrm{mmBtu} / \mathrm{ton}$ of Catalyst & Share $\%$ \\
\hline Natural gas & 8.2 & $95 \%$ \\
\hline Electricity & 0.4 & $5 \%$ \\
\hline Total Energy input & 8.6 & \\
\hline
\end{tabular}

The GREET catalyst module relies on data for the production of ammonium molybdate that is described elsewhere (Benavides et al. 2015), and material and energy flow information for cobalt nitrate. The inventory for cobalt nitrate $\left(\mathrm{Co}\left(\mathrm{NO}_{3}\right)_{2}\right)$ was entirely based on stoichiometric calculations according to the equation: $\mathrm{CoO}+2 \mathrm{HNO}_{3} \rightarrow \mathrm{Co}\left(\mathrm{NO}_{3}\right)_{2}+\mathrm{H}_{2} \mathrm{O}$. The material and energy flow information for $\mathrm{CoO}$ can be found in Burnham et al. (2006).

\subsubsection{Treatment of Spent Catalyst}

The lifetime of a catalyst will depend on processing conditions, feedstock composition, and other factors. The fate of spent catalyst from a biorefinery is unclear, although it is probable that the metal-containing catalysts would need to undergo a recovery process because they may 
be considered too contaminated to be placed in a landfill. It is unlikely that individual refiners and potential bioprocessors would reprocess their own spent catalysts. These catalysts would be shipped to a company, such as Gulf Chemical and Metallurgical Corporation (GCMC) of Freeport, TX. Pomarede (2014) recently outlined the GCMC process that handles spent catalysts from a wide range of hydroprocessing oil refineries. Specifically, they recover molybdenum, vanadium, nickel, cobalt, and alumina from spent catalysts.

The GCMC feedstock spent catalyst is a blend of materials from a number of refiners; therefore, its characteristics and composition presumably varies widely. Table 3 presents a compilation of typical composition ranges reported by Pomarede (2014). Also included in this table are analyses of selected samples of "spent catalysts" reported in the literature. It is noted that petroleum-derived crude oils contain various metals, including high levels of $\mathrm{Ni}$ and $\mathrm{V}$ (up to $600 \mathrm{ppm}$ - primarily as porphyrins), and other metals including $\mathrm{Cu}, \mathrm{Fe}, \mathrm{K}, \mathrm{Mg}, \mathrm{Mn}, \mathrm{Na}, \mathrm{Pb}$, Si, Sn, and Zn (Satterfield 1991, All et al. 1983, Barbooti 2015). Obviously, there is a wide range of catalytic samples and compositions; so process descriptions discussed herein are based on broad generalizations and average compositions.

Although we consider here the use of $\mathrm{Mo} / \mathrm{Ni} / \mathrm{Al}$ as a catalyst for aqueous reforming, these types of catalysts could also be used in hydroprocessing of pyrolysis-derived bio-oils. In this case, the deposition of metals on the catalyst is different than it would be if the catalyst were used in the hydrotreating of petroleum-derive bio-oils. In fact, the makeup of spent catalysts used in processes to hydrotreat bio-oils varies depending on the biomass feedstock. Oasmaa et al (1997) reported that wood pyrolysis liquids tend to have low (between 0.1 and $0.2 \mathrm{wt} \%$ ) ash content as compared to straw pyrolysis liquids $(0.2-0.3 \mathrm{wt} \%)$. In the wood-derived pyrolysis liquid, these authors detected Ca (540 ppm), K (440 ppm), Si (330 ppm), Mg (71 ppm), Fe (71 $\mathrm{ppm}), \mathrm{S}, \mathrm{Al}, \mathrm{P}(30 \mathrm{ppm}), \mathrm{Na}$, and $\mathrm{Zn}(15 \mathrm{ppm})$. The reported CGMC process includes the recovery of $\mathrm{V}$; this metal is not likely deposited on the catalyst in sufficient quantity during the treatment of bio-derived fuels, so process energy requirements would be reduced accordingly because $\mathrm{V}$ recovery, which is energy-intensive, is not necessary.

The following two subsections discuss recovery of spent catalysts used in processes that convert petrochemical and bio-based feedstocks into fuels, respectively. 
TABLE 3 Composition of typical spent catalysts

\begin{tabular}{cccc}
\hline & $\begin{array}{c}\text { Used in Processes to } \\
\text { Convert Petrochemical } \\
\text { Feedstocks } \\
\%\end{array}$ & $\begin{array}{c}\text { Used in Processes to } \\
\text { Convert Biomass } \\
\text { Feedstocks } \\
\%\end{array}$ & $\begin{array}{c}\text { Typical Spent Catalyst } \\
\text { Treated with the GCMC } \\
\text { Process }\end{array}$ \\
$\%$ & 50 & $\%$ \\
\hline $\mathrm{Al}_{2} \mathrm{O}_{3}$ & 50 & 50 & $40-60$ \\
$\mathrm{C}$ & 15 & 17 & $3-25$ \\
$\mathrm{~S}$ & 10 & 10 & $3-15$ \\
$\mathrm{Mo}$ & 7 & 8 & $3-12$ \\
$\mathrm{~W}$ & - & - & $0-12$ \\
$\mathrm{~V}$ & 7 & 1 & $0-12$ \\
$\mathrm{Ni}$ & 3 & 3 & $1-3$ \\
$\mathrm{Co}$ & 2 & 3 & $0-2$ \\
$\mathrm{P}$ & 1 & 1 & $0-3$ \\
$\mathrm{Fe}$ & 1 & 2 & $0-3$ \\
$\mathrm{As}$ & - & - & $0-0.5$ \\
$\mathrm{Ca} / \mathrm{K}$ & 1 & 3 & - \\
$\mathrm{SiO}$ & 2 & 2 & \\
\hline
\end{tabular}

${ }^{1}$ Pomarede, V. (2014)

\subsubsection{Recovered Spent Catalyst Treatment from Petroleum Refineries}

Figure 3 is a schematic of the process GCMC uses to treat spent catalysts used in refineries processing petroleum-derived fuel (Pomarède 2014). Between Llanos et al. (1997) and GCMC documentation (Pomarède 2014), we can construct a description of the basic steps of this process. The composition of the spent catalyst from a petroleum-derived fuel process is given in column 1 of Table 3. First, the spent catalyst is roasted with air and soda ash at temperatures to $800^{\circ} \mathrm{C}$ to burn off residual carbon and hydrocarbons, to convert deposited metals to oxides, and to create soluble sodium salts $\left(\mathrm{Na}_{2} \mathrm{MoO}_{4}, \mathrm{Na}_{2} \mathrm{VO}_{3}\right.$, etc.) The unit is a multiple-stage vertical kiln.

The kiln output proceeds to grinding and leaching stages that isolate highly soluble molybdate and vanadate salts from $\mathrm{Al}, \mathrm{Ni}$, and Co salts. The resulting recovered filter cake consists of alumina and oxides of $\mathrm{Ni}$ and $\mathrm{Co}$. This filter cake enters an electric arc furnace, which produces a fused alumina and $\mathrm{Ni} / \mathrm{Co}$ alloy as a product. The Mo and $\mathrm{V}$ solution is purified to remove $\mathrm{P}, \mathrm{Al}$, and As, along with other contaminants.

Two subsequent steps recover vanadium and molybdenum. In the former, ammonium metavanadate is prepared and recovered. In the latter, $\mathrm{Na}_{2} \mathrm{MoO}_{4}$ is reacted with $\mathrm{HCl}$ to precipitate $\mathrm{MoO}_{3}$. 


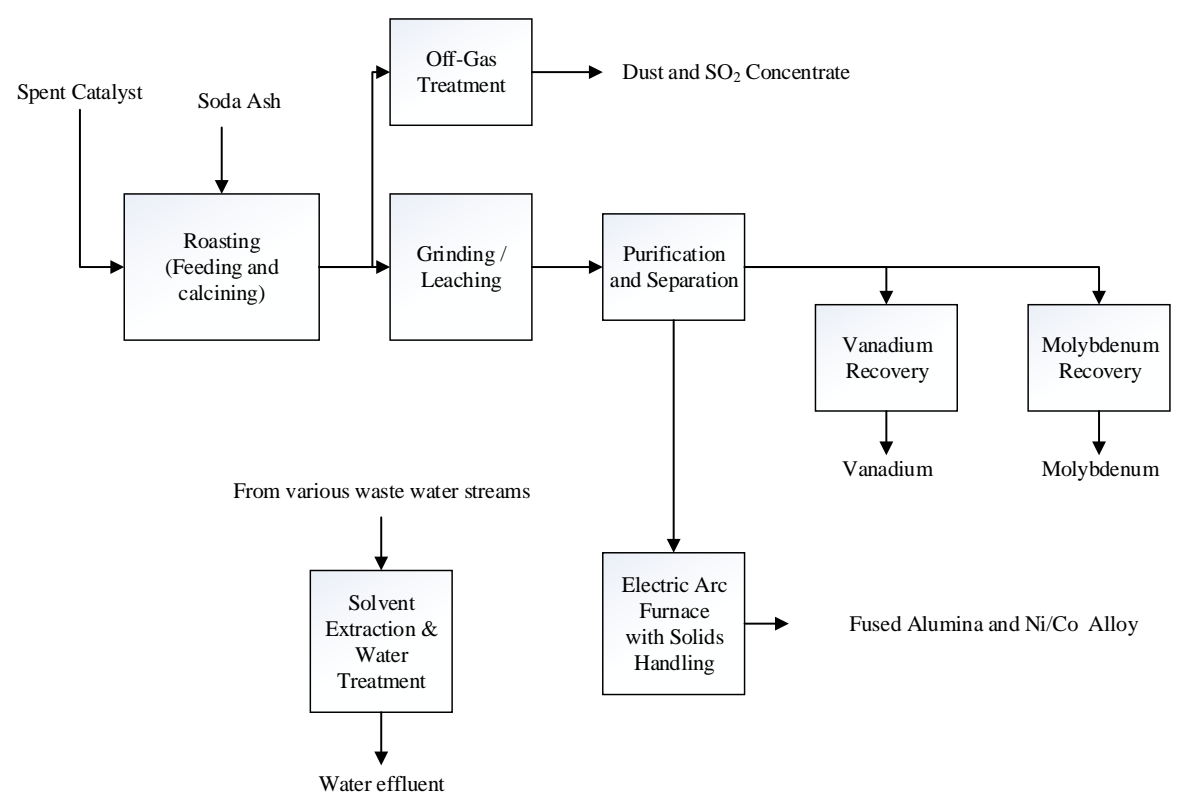

FIGURE 3 GCMC spent catalyst treatment process

Additional steps in this process treat and clean water and air emissions. The overall system includes $\mathrm{pH}$ adjustment, coagulation-flocculation-clarification, and activated carbon and media filtration. Off-gas treatment oxidizes residual hydrocarbon and $\mathrm{CO}$. The off-gas treatment unit includes electro-static precipitators and a fluid-bed scrubber for $\mathrm{SO}_{2}$ removal.

We developed overall material energy balances to describe this process. We summarize the estimated reaction feeds and product yields, along with the energy consumption, in Table 4. In these calculations, we made several assumptions. First, we assumed a basis of 2,000 lbs. of spent catalyst generated from the conversion of petrochemical feedstocks which contains about $50 \%$ alumina, $15 \%$ carbon, $10 \%$ sulfur, $8 \%$ Mo (presumably as a sulfide), $7 \% \mathrm{~V}$ (presumably as a sulfide), $2 \% \mathrm{Co}$ (presumably as sulfide), and nominal levels of other metals. This spent catalyst is recovered, placed in containers, and shipped to an off-site catalyst treatment facility. At the treatment facility, the catalyst is sized and roasted/calcined along with soda ash to prepare soluble salts of recoverable metals. The associated salts are extracted and recovered to isolate product streams of fused alumina, a Ni/Co alloy, vanadium oxide, and molybdenum oxide, at approximate levels of 1000, 100, 250, and $210 \mathrm{lbs}$. per ton of spent catalyst feed. The contaminants from the process are isolated for disposal. These include caustic $\left(317 \mathrm{lbs} . \mathrm{Na}_{2} \mathrm{O}\right.$ or $726 \mathrm{lbs}$. $\mathrm{Na}_{2} \mathrm{SO}_{4}$ if neutralized with $420 \mathrm{lbs}$. acid), and by-product solids (about $100 \mathrm{lbs}$. per ton catalyst fed.)

Gaseous emissions from the process include non-combustion $\mathrm{CO}_{2}$ emissions from coke burnoff. The carbon content of the spent catalyst is approximately $15 \%$, yielding non-combustion $\mathrm{CO}_{2}$ emissions of 0.55 ton $\mathrm{CO}_{2} /$ ton spent catalyst. GREET calculates air emissions from process fuel combustion based on combustion technology (e.g., boilers) emissions factors. This process 
consumes 78 gallons of water per ton of spent catalyst through losses in the drying and WWTP processes.

TABLE 4 Material and energy consumption in treatment of spent catalysts used in the conversion of petrochemical feedstocks

\begin{tabular}{|c|c|c|}
\hline Material & ton/ton of Spent Catalyst & \\
\hline Spent Catalyst & 1 & \\
\hline $\mathrm{Na}_{2} \mathrm{CO}_{3}$ & 0.3 & \\
\hline Water (gal/ ton product) & 78 & \\
\hline Energy & $\begin{array}{c}\text { mmBtu/ton of Spent } \\
\text { Catalyst }\end{array}$ & Share $\%$ \\
\hline Natural Gas & 12 & $55 \%$ \\
\hline Electricity & 10 & $45 \%$ \\
\hline Total Energy input & 22 & \\
\hline
\end{tabular}

The spent catalyst treatment process has a heat input of approximately $12 \mathrm{mmBTU} / \mathrm{ton}$ of feed catalyst plus an associated power consumption of 3,000 kWh/ton of feed catalyst, much of which is consumed by an arc furnace to process the alumina, $\mathrm{Ni}$, and Co. No regenerated catalyst is available from this process. Typically molybdenum is used as a raw material by catalyst manufactures, while the outlet of nickel, cobalt, alumina, and vanadium is in the steel industry.

\subsubsection{Recovered Spent Catalyst Treatment from Bioprocessing Refineries}

As discussed above, a Mo-based "spent catalyst" obtained from a bioprocessing refinery would have a somewhat different composition than that of a spent catalyst from a petroleum refinery (as shown in the second column of Table 3). It is estimated that there would be little recoverable $\mathrm{V}$, but additional levels of $\mathrm{Fe}, \mathrm{Ca}, \mathrm{K}$, and other metals. We considered how the process energy consumption would change given this difference in composition. First, the V recovery unit would not be needed. The heat and power loads of this step are about $20 \%$ and $2 \%$ of that of the petroleum process-derived catalyst treatment facility. There would be a nominal increase in the levels of $\mathrm{K}, \mathrm{Ca}$, and $\mathrm{Fe}$ contained in spent catalysts from processes that convert biomass to fuels. Because steps in the spent catalyst treatment process consume power in order to remove these metals, the power load of a process for treating spent catalysts from bio-based processes would be similar. The product distributions of the process-treating catalysts used in bioprocessing would be similar to that obtained in the spent petrochemical catalyst treatment process, save that no $\mathrm{V}$ would be recovered and by-product solids would increase from 100 to about 200 lbs. per ton of spent catalyst feed. 
We note that the material and energy consumption values we report herein are estimates based on publicly available information. Actual energy and material consumption at these facilities could be very different. The estimates we provide, however, can be used in an analysis to assess the overall contribution of catalysts to biomass conversion process energy consumption and GHG emissions. A sensitivity analysis can be used to assess how variations in the estimates we produce would influence overall biofuel life-cycle GHG emissions estimates.

\section{$2.3 \mathrm{Pt}$ on $\mathrm{Al}_{2} \mathrm{O}_{3}$}

This catalyst can be used in aqueous phase reforming of biomass and other transformations (Alonso et al. 2012). A wide range of hydrogenation reactions are carried out on catalysts containing platinum group metals (PGM) deposited on activated supports. The PGM metals can be deposited at levels from about 0.1 to $5.0 \%$. Very low levels $(0.1 \%)$ are typically used in catalytic mufflers in which a honeycomb cordierite support is covered with a wash coat of $\Upsilon$-alumina. On the other hand, catalysts for refinery purposes are typically in the range of $0.5 \%$ to $3 \% \mathrm{Pt}$ alone or in combinations with other PGMs. Here, emphasis is directed toward the preparation of refinery-type catalysts in which the PGM feed is bulk sponge Pt, with a conceptualization of this process based on several references (Grube 1963, Kauffman 1967, Jackson et al. 1993).

Pt deposition on alumina is achieved using an aqueous solution of a soluble Pt-containing salt such as chloroplatinic acid $\left(\mathrm{H}_{2} \mathrm{PtCl}_{6}\right)$. This acid can be prepared by dissolving $\mathrm{Pt}$ metal sponge in aqua regia, which typically consists of using a 1:3 mixture of concentrated nitric and hydrochloric acids, as summarized in the following reaction:

$$
\mathrm{Pt}+4 \mathrm{HNO}_{3}+6 \mathrm{HCl}->\mathrm{H}_{2} \mathrm{PtCl}_{6}+4 \mathrm{NO}_{2}+4 \mathrm{H}_{2} \mathrm{O}
$$

The $\mathrm{Pt}$ is contacted with concentrated $\mathrm{HCl}$ and subsequently with concentrated $\mathrm{HNO}_{3}$. It is also possible, however, to use a combination of these acids. The mixture is heated to near the reflux temperature, which is about $104^{\circ} \mathrm{C}$, for a short period of about $1 \mathrm{hr}$. It is then cooled and filtered.

The supported catalyst is then prepared using an aqueous solution of chloroplatinic acid $\left(\mathrm{H}_{2} \mathrm{PtCl}_{6}\right)$ with the incipient wetness impregnation (IWI) technique. Specifically, sufficient acid to deposit the desired level of Pt is mixed with sufficient water to fill the pore volume of the alumina. This solution is sprayed onto the dry feed $\Upsilon$-alumina. The resulting solids are then dried at about $104^{\circ} \mathrm{C}$, calcined at about $540^{\circ} \mathrm{C}$ and reduced in hydrogen to form a surface layer of elemental Pt. This mature technology that carries out the Pt impregnation onto alumina, is the subject of an in-depth modeling study (Spieker and Regalbuto 2001). Gaseous emissions from the process include NOx non-combustion emissions; these emissions account for 17,237 $\mathrm{g}$ NOx/ton of spent catalyst. Table 5 summarizes the material and energy flows in this process as based on engineering estimates and calculations of energy required in process steps that involve heating. Approximately 120 gallons of water per ton of catalyst are consumed in the IWI stage of platinum deposition through drying and calcination. The water involved with the aqua regia (240 gal. per ton of catalyst) will presumably be recycled within the process. 
TABLE 5 Material and energy consumption in the production of the $\mathrm{Pt} / \mathrm{\gamma}-\mathrm{Al}_{2} \mathrm{O}_{3}$ catalyst

\begin{tabular}{lcc}
\hline \multicolumn{1}{c}{ Material } & ton/ton of Catalyst & \\
\hline & & \\
Gamma Alumina & 0.98 & \\
$\mathrm{Pt}$ & 0.02 & \\
$\mathrm{HNO}_{3}$ & 0.04 & \\
$\mathrm{HCl}$ & 0.08 & \\
$\mathrm{NaOH}$ & 0.003 & \\
Water (gal/ton product) & 120 & \\
\multicolumn{1}{c}{ Energy } & & \\
& $\mathrm{mmBtu} /$ ton of Catalyst & \\
\hline & & \\
Natural Gas & $5.0^{1}$ & \\
Electricity & 0.07 & \\
Total Energy input & $\mathbf{5 . 1}$ & \\
\hline
\end{tabular}

${ }^{1}$ This energy is assumed to be provided by a natural gas kiln with an efficiency of $80 \%$.

As is the case with CoMo and NiMo on $\gamma$-alumina catalysts, it is unlikely that individual refiners and potential bioprocessors would reprocess their own spent catalysts. There are a number of PGM recovery companies that process spent catalysts and recycled auto catalytic units. Catalyst recovery processes can be categorized as: (1) hydrometallurgical or solution extraction, (2) pyrometallurgical, or (3) gas-phase volatilization or selective chlorination (Kim et al. 2009, Aberasturi et al. 2011, Barakat et al. 2004). There are insufficient data to estimate the shares of each of these processes as applied to treatment of spent $\mathrm{Pt} / \gamma-\mathrm{Al}_{2} \mathrm{O}_{3}$ catalysts. We discuss two of these options: (1) extracting Pt using aqua regia (hydrometallurgical approach) and (2) pyrolysis using a metal extractant, such as Fe or $\mathrm{Cu}$. The reference "spent catalyst" consists of $2 \% \mathrm{Pt}$ on $\gamma$-alumina with other contaminants, including carbonaceous coke.

In the aqua regia extraction process, the spent catalyst is recovered and calcined to burn off carbonaceous deposits. Calcination at $870^{\circ} \mathrm{C}$ has been suggested (Appell 1958) to convert the alumina support from the $\gamma$ to $\alpha$ phase, thereby greatly reducing the surface area and forming a relatively inert surface that acids cannot attack as effectively. The catalyst is partially cooled and contacted with aqua regia. Several studies (Kim et al. 2009, Aberasturi et al. 2011, Barakat et al. 2004) have investigated the contact time and temperature. In general, the residence time is about $1.5 \mathrm{hr}$, the process temperature is about $115^{\circ} \mathrm{C}$, and the liquid-to-solid ratio required is about 5:1 or greater to achieve over $95 \% \mathrm{Pt}$ recovery. The solids are filtered and the solution is treated to recover solid $\mathrm{Pt}$ for processing or resale. It is assumed that the recovered acids are recycled within the process. The various PGM components can be separated using ion exchange or chromatography using their chloro-complexes (Bernardis et al. 2005). Table 6 contains the material and energy consumption associated with the aqua regia spent catalyst treatment process. Approximately $80 \%$ of the total input water (1198 gal. per ton of spent catalyst) will be recycled 
within in the process while the remaining water ( 240 gal. per ton of spent catalyst) will have to be handled in a waste water treatment facility. Table 6 only presents the WWTP water losses.

TABLE 6 Material and energy consumption associated with the aqua regia spent catalyst process

\begin{tabular}{lcc}
\hline \multicolumn{1}{c}{ Materials } & ton/ton of Spent Catalyst & \\
\hline & & \\
Spent catalyst & 1 & \\
$\mathrm{HNO}_{3}$ & 0.03 & \\
$\mathrm{HCl}$ & 0.08 & \\
Water (gal/ ton product) & 48 & Share \% \\
\hline \multicolumn{1}{c}{ Energy } & & \\
\multicolumn{3}{c}{ mmBtu/ton of Spent Catalyst } \\
Natural gas & $6.3^{1}$ & $1 \%$ \\
Electricity & 0.07 & \\
Total Energy input & $\mathbf{6 . 3}$ & \\
\hline
\end{tabular}

${ }^{1}$ This energy is assumed to be provided by a NG kiln with an efficiency of $80 \%$.

Thermal recovery of PGMs using the pyrometallurgical spent catalyst treatment process has been reviewed by Benson et al. (2000). Specifically, crushed recycled solids, with the addition of limited amounts of $\mathrm{Fe}$ or $\mathrm{Cu}$ as a flux or carrier, are heated to temperatures in the range of 1500 to $1700^{\circ} \mathrm{C}$ to isolate PGM solids in a slag layer. (This approach is stated to be an extension of the Johnson-Matthey [JM] Process.) While the settling times of PGM solids in the slag layer are short (at about 10 minutes for the JM Process), estimating the heat load to bring the mass to temperature is a challenge. In addition, a recent publication of Tetronics International discusses the environmental impacts of plasma-smelting of spent catalysts (Johnson and Deegan, 2014). This approach includes a continuous plasma furnace with a feed blend of spent catalyst with fluxes (typically lime and/or silica) to produce a slag composition with a melting point in the range of 1350 to $1450^{\circ} \mathrm{C}$. To accelerate separation of the PGM, a "liquid solvent" of either iron or copper is added. This solvent sinks through the slag phase and dissolves the PGM. The resulting metal phase that settles in the hearth is tapped from the furnace for subsequent PGM recovery. As a note, the temperature of the plasma is on the order of $10,000 \mathrm{~K}$ at its center. The off-gas from the furnace passes through a post-combustion chamber and then through a hightemperature filter before discharge to the atmosphere. It is noted that there is no wet scrubbing, thereby eliminating liquid waste. There is subsequent metal processing to recover the commercial-grade PGM components.

The energy and material requirements are limited only to "secondary PGM sources," namely spent catalyst, and are shown in the Table 7 . The basis for these values is that of a feed catalyst of one ton containing $2 \mathrm{wt} \%$ Pt to the smelting step. 


\section{TABLE 7 Material and energy consumption associated with the}

pyrometallurgical spent catalyst process

\begin{tabular}{lcc}
\hline \multicolumn{1}{c}{ Materials } & ton/ton of Spent Catalyst & \\
\hline & 1 & \\
Spent catalyst & 0.14 & \\
Iron ore $^{1}$ (Magnetite) & 0.1 & \\
Lime & mmBtu/ton of Spent Catalyst & Share \% \\
\hline \multicolumn{1}{c}{ Energy } & 0.05 & $100 \%$ \\
Electricity & $\mathbf{0 . 0 5}$ & \\
Total Energy input & & \\
\hline
\end{tabular}

${ }^{1}$ Copper ore is used as a proxy.

\subsection{TAR REFORMING CATALYST}

The basis of the structure of the tar reforming catalyst is the structure in the Magrini-Bair et al. (2007) report. The catalyst is assumed to be composed of 5\% nickel oxide (NiO), $4 \%$ potassium oxide $\left(\mathrm{K}_{2} \mathrm{O}\right)$, and $8 \%$ magnesium oxide $(\mathrm{MgO})$ on an $84 \% \gamma$-alumina $\left(\gamma-\mathrm{Al}_{2} \mathrm{O}_{3}\right)$ support (all percentages given by weight).

To prepare the tar reforming catalyst from its precursors, the $\gamma$-alumina support is wetted with an aqueous solution consisting of nickel nitrate $\left[\mathrm{Ni}\left(\mathrm{NO}_{3}\right)_{2}\right]$, magnesium nitrate $\left[\mathrm{Mg}\left(\mathrm{NO}_{3}\right)_{2}\right]$ and potassium nitrate $\left(\mathrm{KNO}_{3}\right)$. Finally, the mixture is calcined to yield the tar reforming catalyst that contains the oxidized form of the metals (Lloyd, 2011).

Among the material inputs to the tar reforming catalyst, the material and energy flow data for $\mathrm{KNO}_{3}$ and crude $\mathrm{Al}_{2} \mathrm{O}_{3}$ exist in GREET. $\mathrm{Ni}\left(\mathrm{NO}_{3}\right)_{2}$ and $\mathrm{Mg}\left(\mathrm{NO}_{3}\right)_{2}$ are assumed to be produced by reacting nickel and magnesium metal with nitric acid, respectively. The energy and material flow data for the production of nickel, magnesium, and nitric acid are available in GREET. Finally, the energy consumption of the final calcining process is $2 \mathrm{mmBtu} /$ ton catalyst based on Dunn et al. (2014b). This energy is assumed to be provided by a natural gas kiln with an efficiency of $80 \%$. 


\section{CHEMICALS FOR INDIRECT GASIFICATION AND MIXED ALCOHOL SYNTHESIS}

Dutta et al. (2011) developed a process model for indirect gasification of pine to produce ethanol and mixed alcohols. In this process, olivine serves as the heat transfer medium for the indirect gasification of the biomass. During gasification, syngas $\left(\mathrm{CO}\right.$ and $\left.\mathrm{H}_{2}\right)$ forms along with char and tar, which adhere to the olivine. The olivine is recovered, and the char and tar are burned off with oxygen to reheat the olivine substrate. DEPG is used to remove most of the $\mathrm{H}_{2} \mathrm{~S}$ and a portion of the $\mathrm{CO}_{2}$ generated during gasification. Tars, methane, and light hydrocarbons are reformed to syngas in a circulating, fluidized, solid catalyst system that resembles a smallscale fluid catalytic cracker (FCC), complete with reforming and regeneration operations in separate beds. Finally, the syngas is converted to yield ethanol and mixed alcohols through a catalytic alcohol synthesis step using an alcohol synthesis catalyst.

\subsection{OLIVINE}

Olivine is a mineral form of magnesium-iron silicates. It has a high melting point and stores heat well. Accordingly, it is commonly used in high-temperature applications, such as indirect gasification. Olivine is commercially available in the United States, but only roughly one-third is produced domestically; the balance is imported from Norway, which has a large reserve of olivine ore (Kramer, 2001). We use these shares in GREET when developing the energy and material flows of olivine production.

Olivine needs very little processing before it can be used in a chemical process, so the main steps in its production are mining, size reduction, and transportation. We include the latter step because of the significant transportation distance between Norway and the United States. Table 8 contains mining energies for several different metals from the GREET vehicle cycle module (GREET 2). The mining energies for these different metals are comparable, so we adopt their average for the mining of olivine $(2.8 \mathrm{mmBtu} / \mathrm{ton})$. It was also necessary to estimate the breakdown of the total mining energy among different energy types, such as diesel and natural gas. We did so on the basis of the energy type shares for metals mining in GREET. The share of diesel fuel ranges from $19 \%$ to $48 \%$ in Table 8 . To be conservative, we used the lower end of this range because production of $1 \mathrm{mmBtu}$ electricity is generally more energy intensive than production of $1 \mathrm{mmBtu}$ of diesel fuel. We assumed that the diesel fuel consumption includes that for beneficiation, which is generally the case for metals in GREET 2. This assumption should not greatly affect the estimate of olivine mining energy because olivine requires minimal processing. 
TABLE 8 Energy consumption for metal mining (GREET2)

\begin{tabular}{lcl}
\hline \multicolumn{1}{c}{ Metal } & $\begin{array}{c}\text { Energy Input } \\
(\mathrm{mmBtu} / \text { ton })\end{array}$ & \multicolumn{1}{c}{ Non-Electric Share } \\
\hline & & \\
Copper & 2.15 & $48 \%$ Diesel \\
Iron ore & 1.80 & $10.8 \%$ NG, 10.2\% Oil \\
Lead & 2.59 & $19 \%$ Diesel \\
Manganese & 3.72 & $19 \%$ Diesel \\
Nickel & 2.66 & $42.7 \%$ Oil, 37.5\% Natural Gas \\
Zinc & 3.72 & $19 \%$ Diesel \\
\hline
\end{tabular}

The remaining step in the olivine supply chain is to transport it to the biorefinery. For 1 ton of olivine, we assume that the portion produced in the United States travels by rail for 100 miles. We selected this distance because 100 miles separates an olivine mine and processing facility in the State of Washington. The Norwegian olivine travels across the ocean by ocean tanker for 3,700 miles (the distance between Oslo and New York City) and then domestically by rail for 100 miles (the distance from New York City to Bethlehem, Pennsylvania, where more than half of the imported olivine is consumed for steel production [Kramer, 2001]). The energy intensities of rail and ocean tanker transportation in GREET are $270 \mathrm{Btu} /$ ton-mile and 43 Btu/ton-mile, respectively. Tankers consume residual oil, while locomotives burn diesel. Table 9 reports the purchased energy consumed during olivine production. Purchased energy is the actual amount of energy consumed at the olivine production facility. From these inputs, GREET calculates the full fuel cycle energy consumed in olivine production on the basis of GREET data for upstream impacts of producing diesel, residual oil, and natural gas (NG).

TABLE 9 Purchased energy inputs to olivine production

\begin{tabular}{lcc}
\hline \multicolumn{1}{c}{ Fuel Type } & $\begin{array}{c}\text { Mining } \\
(\mathrm{mmBtu} / \mathrm{ton})\end{array}$ & $\begin{array}{c}\text { Transportation } \\
(\mathrm{mmBtu} / \mathrm{ton})\end{array}$ \\
\hline Diesel & 0.5 & \\
Residual oil & 0 & 0.03 \\
Electricity & 2.3 & 0.11 \\
Total (Direct) & 2.8 & 0 \\
\hline
\end{tabular}

\subsection{DEPG}

DEPG is a specific form of polyethylene glycol with functional end groups that aid in capturing $\mathrm{H}_{2} \mathrm{~S}$ and $\mathrm{CO}_{2}$. To produce DEPG, ethylene oxide is polymerized into polyethylene glycol. The energy and material flow for production of ethylene oxide is from the GREET bioproducts module (Dunn et al., 2014a). The purchased energy consumed in the polymerization 
of polyethylene terephthalate, documented in an American Chemistry Council-sponsored life cycle assessment of polymers (Franklin Associates, 2011), is used as a representation of the energy consumed in ethylene oxide polymerization. Overall, the purchased energy consumed in the production of 1 ton of DEPG is $0.0015 \mathrm{mmBtu}$ diesel fuel, $2.4 \mathrm{mmBtu} \mathrm{NG}, 0.96 \mathrm{mmBtu}$ coal, and $0.33 \mathrm{mmBtu}$ electricity (Franklin Associates, 2011).

\subsection{MgO}

A European Commission report (2010) included reports of energy consumption at $14 \mathrm{MgO}$ plants in 2008, which ranged from 5 to $10 \mathrm{mmBtu} /$ ton $\mathrm{MgO}$. We adopted the average of the energy intensities in this report as the energy intensity of $\mathrm{MgO}$ production in GREET: $7.7 \mathrm{mmBtu} /$ ton. Natural gas was the major process fuel used in kilns (European Commission, 2010).

\subsection{ALCOHOL SYNTHESIS CATALYST}

The composition of the alcohol synthesis catalyst is approximated from U.S. Patent $4,882,360$ (Stevens, 1989). It is assumed to be composed (all percentages given by weight) of $12 \%$ molybdenum oxide $\left(\mathrm{MoO}_{3}\right), 2 \%$ potassium oxide $\left(\mathrm{K}_{2} \mathrm{O}\right), 11 \%$ cobalt oxide $(\mathrm{CoO})$, and $68 \%$ carbon support (activated carbon). The remaining weight is assumed to be sulfur from hydrogen sulfide, which displaces oxygen during chemical reduction of the surface. The catalyst is prepared by contacting activated carbon with a hot aqueous solution of soluble Mo salt (i.e., ammonium heptamolybdate) and cobalt nitrate $\left[\mathrm{Co}\left(\mathrm{NO}_{3}\right)_{2}\right]$ in a phosphoric acidic solution. After drying, the solids are contacted with the caustic $\mathrm{KOH}$ solution and subsequently dried. The resulting catalyst is then sulfided (Stevens, 1989).

To build the material and energy flows in the alcohol synthesis catalyst supply chain, we relied on existing GREET data in several cases, such as for $\mathrm{KOH}$. $\mathrm{Co}\left(\mathrm{NO}_{3}\right)_{2}$ is produced by reacting $\mathrm{CoO}$ with nitric acid (Richardson, 2000), and the energy and material flow data for production of both $\mathrm{CoO}$ and nitric acid are available in GREET. Ammonium heptamolybdate is obtained by reacting ammonia solution with $\mathrm{MoO}_{3}$, while $\mathrm{MoO}_{3}$ is produced by calcining $\mathrm{MoS}_{2}$ ore (Stiefel, 2000). We describe the production of ammonium heptamolybdate also known as ammonium molybdate in a separate report (Benavides et al. 2015). In the United States, sulfur is mainly produced as a low-value byproduct of petroleum refineries and from purification of natural gas. We assign refinery energy consumption and emissions to the main, high-value refinery and natural gas processing products and treat the byproduct sulfur as burden-free (Johnson et al., 2013). 


\subsubsection{Activated Carbon}

The catalyst module contains data for the production of activated carbon. Activated carbon is very porous and has a high surface area. Environmental and industrial industries are among those that use activated carbon in applications such as adsorption, reduction, and catalysis (Baker, 2004). Activated carbon is sold in granular (GAC), powdered (PAC), extruded, and fibrous formats. However, the most common forms are GAC and PAC. The major difference between PAC and GAC is that PAC is ground more finely than GAC (Baker, et al., 2003).

Although almost any carbonaceous material can be converted into an activated carbon product, the starting materials used in the vast majority of industrial production operations are coal, coke, wood chips or sawdust, coconut shells, petroleum fractions and peat (Camara et al., 1999). For catalysis applications of activated carbon, very low levels of impurities are required, which limits the possible starting materials to those capable of yielding a high-purity carbon product. Petroleum fractions and peat contain impurities that make them unsuitable as a feedstock for activated carbon. We include both woody biomass and coal as activated carbon feedstocks in GREET.

In the case of woody biomass, we adopt existing GREET data for the collection and processing of forest residue (Wang et al., 2013) to build analysis of activated carbon from a woody feedstock. The initial step in the production of activated carbon from wood chips is the slow pyrolysis of the chips to yield biochar. The yield of biochar from pyrolysis is assumed to be 30\% (Wang et al., 2014). The pyrolysis process produces flue gas and bio-oil that could be combusted to generate energy. The slow pyrolysis of the wood chips could therefore be energy self-sufficient, possibly producing excess energy depending on the heat integration (Wang et al., 2014). This extra energy could be applied towards the second step in the production of activated carbon (the activation step) or for other uses. Without precise information on heat integration or energy use at an actual facility producing activated carbon, however, we adopt the conservative assumption that the extra energy is discarded. Biochar can be activated with physical or chemical techniques. The most common method is a simple thermal treatment (physical activation) with an oxidizing gas, most often steam, $\mathrm{CO}_{2}$, or a combination of both (Camara et al., 1999). Based on U.S. Patent 20090317320 A1 (Srinivasachar et al., 2009), we assume the biochar is activated with steam at a temperature of $875^{\circ} \mathrm{C}$ with a residence time of 90 minutes and a conversion yield of $67 \%$ from biochar to activated carbon. The mass ratio of biochar/steam is $0.92: 1$, and the heat needed for the production of steam and the activation process is calculated to be $10 \mathrm{mmBtu} /$ ton activated carbon (Srinivasachar et al., 2009). We assume this heat is provided by a natural gasfired kiln with an efficiency of $80 \%$. We also assume any non-combustion $\mathrm{CO}_{2}$ emissions are biogenic; these are not counted among the $\mathrm{CO}_{2}$ emissions assigned to forest residue-derived feedstocks. The forest-residue-derived activated carbon does store some biogenic carbon and receives a credit for this storage in GREET. If it is combusted or decays at end-of-life, this biogenic carbon would be released to the atmosphere, we assume as $\mathrm{CO}_{2}$. This release is accounted for in GREET in the pathway for activated carbon.

Coal is the second activated carbon raw material we considered. It has a high carbon content but relatively low volatile content, allowing producers to obtain high product yields (McDougall, 1991). 


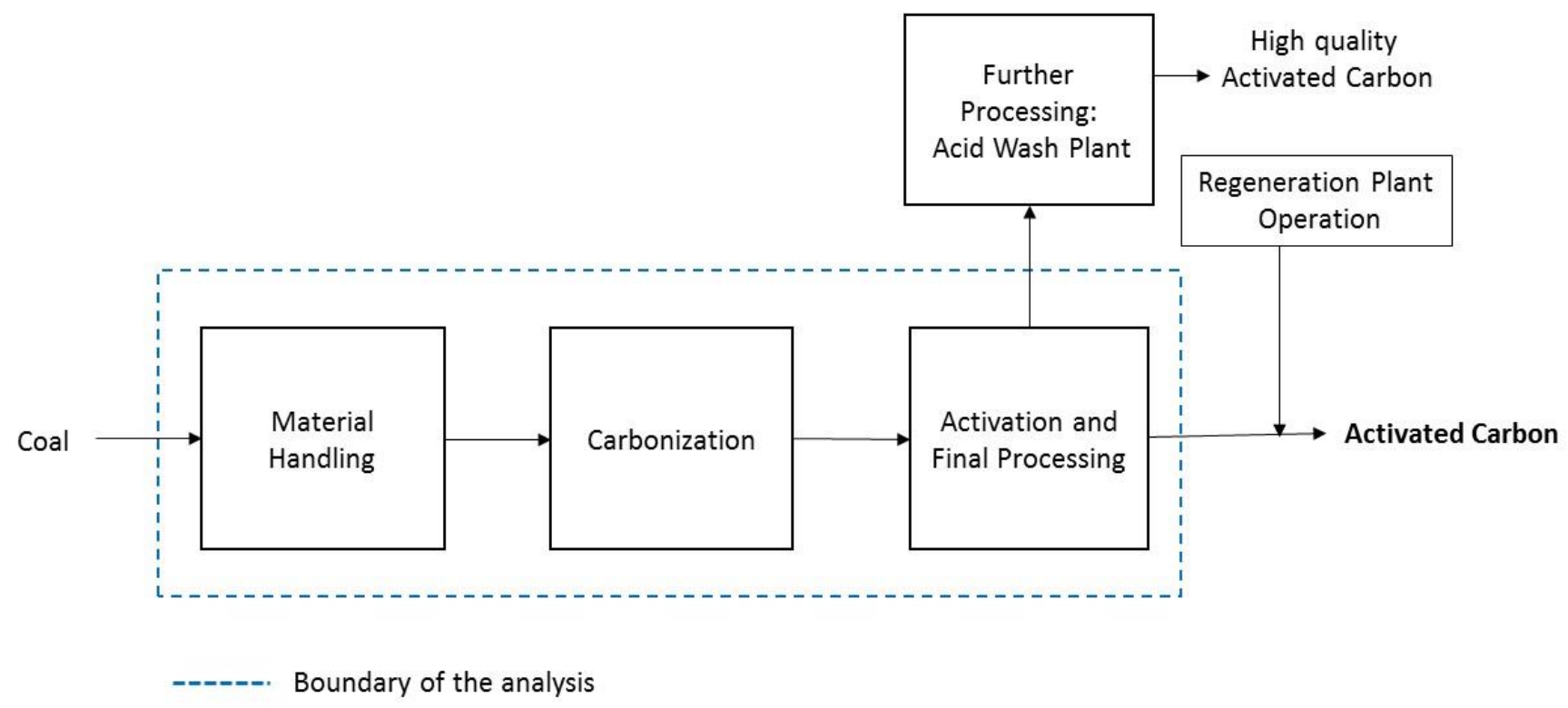

FIGURE 4 General scheme of activated carbon production from coal

To estimate the material and energy flows associated with activated carbon production, we rely upon the Title V air permits for Cabot Norit Americas (Cabot) located in Pryor, Oklahoma (Cabot Norit Americas, Inc., 2014). This facility owns and operates a virgin activated carbon manufacturing plant and a spent activated carbon regeneration facility. The permit includes information about the equipment used in basic operation areas of material handling and preparation; carbonizing, activation, finished product packaging, acid wash plant operations, and regeneration plant. Figure 4 illustrates the general scheme for activated carbon production from coal based on the description presented in the permit (Cabot Norit Americas, Inc., 2014). Cabot can process 78,840 ton per year of coal and operates its plant 8,760 hours per year (Cabot Norit Americas, Inc., 2014). The raw material consists of $81 \%$ of four types of bituminous coal, $12 \%$ subbituminous coal, and $7 \%$ pitch. In 2009, Cabot produced 15,117 tons of activated carbon from 50,162 ton of coal, which represents a $30 \mathrm{wt} \%$ yield. This yield agrees with Marsh and Rodríguez Reinoso (2006), who report that the yield of activated carbon from coal is around $30 \mathrm{wt} \%$, which is generally larger than the activated carbon yield from lignocellulosic material (i.e. 20 to $30 \mathrm{wt} \%)$. Based on the capacity (78,840 tons coal/yr) and the expected $30 \mathrm{wt} \%$ yield, we therefore assumed that the facility produces 23,652 tons activated carbon per year. Figure 4 also presents a section for further processing, which involves the acid wash plant and regeneration. The acid wash plant is an auxiliary process that allows the production of a higher quality activated carbon required by certain industrial processes, such as food processing or pharmaceuticals. In the acid wash plant, hydrochloric acid $(\mathrm{HCl})$ is diluted to remove, through a wash or leach operation, acid soluble constituents from activated carbon produced by the virgin plant. The regeneration plant recovers spent activated carbon that has absorbed chemical constituents in previous process. We did not include these processes in our analysis. In the following subsections, we explain the different processes that Cabot Norit Americas uses to produce activated carbon from coal. 
Raw material handling and preparation: According to Cabot Norit Americas, Inc. (2014), the raw material arrives at the plant via rail or truck from difference sources. Coal and coal tar pitch are unloaded into the raw material unloading building. Next, these raw materials are moved to the working storage pile. Before the carbonization and activation steps, the raw material undergoes drying and sizing operations to render the material homogeneous. A thermal dryer removes moisture from the coal. Next, this raw material is pulverized and ground with the pitch and compacted; the resulting briquettes are milled to the desired particle size. Phosphoric acid is added to incoming subbituminous coal as a processing aid (Cabot Norit Americas, Inc., 2014). Table 10 catalogues the equipment involved in material handling and preparation, and the assumptions and/or data sources we used to estimate their energy consumption.

TABLE 10 Equipment used during raw material handling and preparation to produce activated carbon (Cabot Norit Americas, Inc., 2014)

\begin{tabular}{|c|c|c|c|}
\hline Unit & $\begin{array}{l}\text { Process Rate } \\
\text { (ton/hr) }\end{array}$ & Fuel Type & $\begin{array}{l}\text { Additional } \\
\text { Information }\end{array}$ \\
\hline Crusher ${ }^{1}$ & 10 & Diesel & Fuel consumption $1.3 \mathrm{gal} / \mathrm{hr}$ \\
\hline Compactor $^{2}$ & 10 & Electricity & Electric motor power: $60 \mathrm{kWh} / \mathrm{ton}$ \\
\hline Bowl mill ${ }^{3}$ & 10 & Electricity & Electric motor power: $250 \mathrm{HP}$ \\
\hline Truck Unloading & 20 & Diesel & Power consumption: $1320 \mathrm{~kW}$ \\
\hline Front end loader ${ }^{4}$ & 200 & Diesel & Energy required:5110 Btu/ton \\
\hline Thermal dryer ${ }^{5}$ & 10 & Natural gas & Energy required: $0.416 \mathrm{mmBtu} /$ ton coal \\
\hline Air compressor ${ }^{6}$ & NR & Diesel & Fuel consumption: $15 \mathrm{gal} / \mathrm{hr}$ \\
\hline \multicolumn{4}{|c|}{$\begin{array}{l}\text { Assuming the Jaw crusher has a 6-gallon fuel tank (GMC Global Mining Crusher, 2014). Most of the crushers } \\
\text { for coal preparation produced by GMC global mining crusher have fuel consumption of } 1.3 \text { gallons of diesel per } \\
\text { hour. }\end{array}$} \\
\hline \multicolumn{4}{|c|}{ Assuming a screw press as compaction technology (Grover and Mishra, 1996) } \\
\hline \multicolumn{4}{|c|}{$\begin{array}{l}\text { Assuming that the bowl mill used is Raymond bowl mill coal pulverizer. Capacity of the bowl mill is } 20300 \mathrm{lb} / \mathrm{hr} \\
\text { (Wabash Power Equipment Company, 2013) }\end{array}$} \\
\hline \multicolumn{4}{|c|}{ Assuming similar equipment used in surface coal mines (U.S. Department of Energy, 2013) } \\
\hline \multicolumn{4}{|c|}{5 (U.S Environmental Protection Agency, 1998) } \\
\hline \multicolumn{4}{|c|}{$\begin{array}{l}6 \text { The model of the air compressor is a Caterpillar C9-300 HP. The fuel consumption was taken from another } \\
\text { permit of a portable crushing and screening plant where the same air compressor model was used (Twigg-Smith } \\
\text { et al., 2004) }\end{array}$} \\
\hline \multicolumn{4}{|l|}{ NR: Not reported } \\
\hline
\end{tabular}

We estimated hourly fuel consumption rates for trucks based on data in their manufacturers' websites and handbooks. We multiplied the hourly volumetric fuel consumption rate by the lower heating value of diesel $(128450 \mathrm{Btu} / \mathrm{gal})$ to calculate the energy consumption rate. In the case of hauling trucks, we used the following equation to compute the fuel consumption (FC) (Kecojevlc and Komljenovic, 2010): 


$$
\mathrm{FC}=\frac{\mathrm{CSF} * \mathrm{P} * \mathrm{LF}}{\mathrm{FD}}
$$

where FC is the hourly fuel consumption, CSF is the engine-specific fuel consumption at full power $(0.24 \mathrm{~kg} / \mathrm{kW} / \mathrm{hr}), \mathrm{P}$ is the power of the engine $(1320 \mathrm{~kW}), \mathrm{LF}$ is the engine load factor, and FD is the fuel density $(0.85 \mathrm{~kg} / \mathrm{L}$ for diesel). For the LF, we used $35 \%$, which is recommended for light utility equipment such as pulling scrapers, stock piles, and coal piles (Caterpillar, 2014). The power is based on a Caterpillar 789C hauling truck (RitchieSpecs, 2015).

Table 11 summarizes the energy consumed in this section of the facility: $14.4 \mathrm{mmBtu}$ per hour or $5.3 \mathrm{mmBtu}$ per ton of activated carbon produced. Of this energy, $52 \%$ is consumed in diesel equipment such as crushers, trucks for unloading material, front end loaders, and in the air compressor. The thermal dryer is the only unit that uses natural gas, accounting for $29 \%$ of consumed energy, while the compactor and bowl mill consume electricity that constitutes $18.6 \%$ of the total consumed energy.

TABLE 11 Purchased energy inputs for material handling and coal preparation (Cabot Norit Americas, Inc., 2014)

\begin{tabular}{cccc}
\hline Fuel & mmBtu/hr & $\begin{array}{c}\text { mmBtu/ton of } \\
\text { Activated Carbon }\end{array}$ & Fuel Share \\
\hline Diesel & 7.6 & 2.8 & $52 \%$ \\
Electricity & 2.7 & 1.0 & $19 \%$ \\
Natural gas & 4.2 & 1.5 & $29 \%$ \\
Total & 14.4 & 5.3 & - \\
\hline
\end{tabular}

We also account for non-combustion emissions, such as particulate matter emissions from materials handling equipment or drying equipment. Furthermore, non-combustion $\mathrm{CO}_{2}$ emissions arise during activated carbon production. We used data from the permit (Cabot Norit Americas, Inc., 2014) to estimate non-combustion emissions. Permit emissions data are not-toexceed limits agreed upon by a facility and a regulatory agency. These data often overestimate actual emissions at a facility. Accordingly, they serve as worst case emissions estimates. Table 12 presents the material balance that indicates the amount of $\mathrm{CO}_{2}$ emitted as a noncombustion emission. Table 13 presents PM emissions associated with materials handling and final processing. All PM emissions are assumed to be $\mathrm{PM}_{10}$. 
TABLE 12 Non-combustion emission of $\mathrm{CO}_{2}$

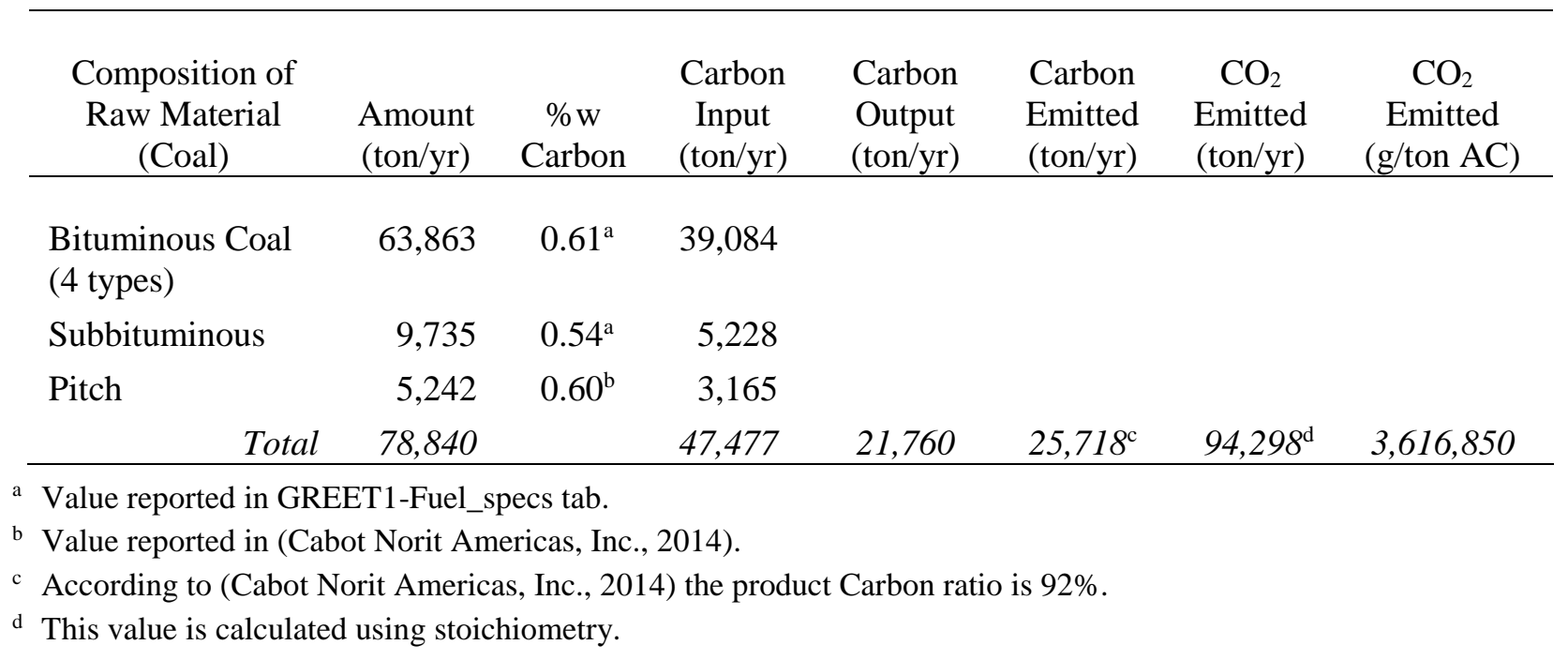

TABLE 13 PM10 non-combustion emissions (Cabot Norit Americas, Inc., 2014)

\begin{tabular}{cccc}
\hline & $\begin{array}{c}\text { Material Handling } \\
\text { and Preparation }\end{array}$ & $\begin{array}{c}\text { Final } \\
\text { Processing }\end{array}$ & Total $\mathrm{PM}_{10}$ \\
\hline ton $\mathrm{PM}_{10} / \mathrm{yr}$ & 34 & 0.23 & 34.2 \\
$\mathrm{~g} \mathrm{PM}_{10} /$ tons & 1,300 & 9 & 1,309 \\
activated carbon & & & \\
\hline
\end{tabular}

Carbonization: In the carbonization process, the raw material is transformed through pyrolysis between $600-900^{\circ} \mathrm{C}$. This step, which occurs in an anaerobic environment with inert gases, is carried out in furnaces such as rotary kilns, multiple hearth furnaces, or fluidized bed furnaces. The resulting material contains mostly carbonized material, or "char," as well as some tars, oils, and gases. At Cabot, natural gas is the main source of energy. Carbonization occurs in two cylindrical kilns, designated as the primary and secondary carbonizers, which rotate very slowly. The carbonization step removes water, volatile organic compounds (VOCs), and reduces the material to carbon. According to Cabot Norit Americas, Inc. (2014) this process requires $48 \mathrm{mmBtu}$ per hour or $18 \mathrm{mmBtu}$ per ton of activated carbon produced. The primary carbonizer, secondary carbonizer, and the two activator furnaces (activation process) use afterburners and waste heat boilers to control emissions of VOC and toxic compounds. The secondary carbonizer has a multiclone particulate separator for PM control after the exhaust stream exits the waste heat boiler. Waste heat boilers follow each afterburner.

Activation and final processing: The char obtained after carbonization does not have a high adsorption capacity because its pore structure is not fully pronounced. Activation improves this property and the surface of the material via the destruction of the carbon structure using the oxidation process. There are two types of activation processes: chemical and physical (or 
thermal). Physical activation is the most common method of activation and is used at Cabot Norit Americas. Cabot uses two multiple-hearth furnaces as the activator furnaces. They require $50 \mathrm{mmBtu}$ per hour or $19 \mathrm{mmBtu}$ per ton of activated carbon produced. These activator furnaces use heat from natural gas combustion, along with steam.

Final processing includes finished product packing operations - additional handling, screening, storing, and loading of the activated carbon into bags for final shipment to customers. Depending on customer requirements, additional milling may be needed to create powdered products (i.e., PAC). According to Cabot Norit Americas, Inc. (2014), nine grams of $\mathrm{PM}_{10}$ are released per ton of activated carbon during final processing of activated carbon (see Table 13).

Process heating: Finally, we included the energy consumed by the natural gas-fired boilers used throughout the process. Boilers consume $49 \mathrm{mmBtu}$ per hour or $18 \mathrm{mmBtu}$ per ton of activated carbon produced.

Table 14 lists the operating units in the carbonization, activation, and process heating sections of the Cabot Norit Americas plant. It also lists the process rate and energy inputs for some of these pieces of equipment. The heat is supplied indirectly by gas-fired burners that are installed in the heating jackets, which are positioned on the outside of each carbonizer. To activate the carbonizer output, two activator furnaces are used to create a porous structure in the carbon. 
TABLE 14 Carbonization, activation, and process heating equipment and energy inputs (Cabot Norit Americas, Inc., 2014)

\begin{tabular}{|c|c|c|c|}
\hline Unit & $\begin{array}{l}\text { Process Rate } \\
\text { (ton/hr) }\end{array}$ & $\begin{array}{l}\text { Maximum Total } \\
\text { Heat Input } \\
\text { (mmBtu/hr) }\end{array}$ & $\begin{array}{l}(\mathrm{mmBtu} / \\
\text { ton AC) }\end{array}$ \\
\hline \multicolumn{4}{|l|}{ Carbonization } \\
\hline Primary carbonizer/ after burner/waste heat boiler & 9 & 12 & \multirow{4}{*}{18} \\
\hline $\begin{array}{l}\text { Secondary carbonizer/multiclone/after burner/waste } \\
\text { heat boiler }\end{array}$ & 9.8 & 18 & \\
\hline Primary carbonizer heating jacket & - & 8 & \\
\hline Secondary carbonizer heating jacket & - & 10 & \\
\hline \multicolumn{4}{|l|}{ Activation } \\
\hline East activator furnace/after burner & 57 & 25 & \multirow{2}{*}{19} \\
\hline West activator furnace/after burner & 57 & 25 & \\
\hline \multicolumn{4}{|l|}{ Process heating* } \\
\hline Package boiler & - & 24.5 & \multirow{2}{*}{18} \\
\hline Boiler NSPS Subpart DC & - & 24.5 & \\
\hline
\end{tabular}

* Note: It is possible that some of the energy used in process heating could be used in the treatment of spent activated carbon. The permit, however, does not specify whether any of this energy is indeed consumed in this other process that happens at the same facility. We therefore assume that all energy produced by these boilers is consumed in the process to make virgin activated carbon.

The total $\mathrm{CO}_{2}$ emissions (including combustion and non-combustion emissions) calculated in GREET are 7,878,293 $\mathrm{g} \mathrm{CO}_{2}$ per ton of coal-derived activated carbon. This value agrees with results from other LCAs of coal-derived activated carbon reported in the literature, which average value is around 8,032,302 $\mathrm{g} \mathrm{CO}_{2}$ per ton of coal-derived activated carbon (Bayer et al., 2005; Saffaria, S., 2009; He, K., 2012;Novinda Market, 2012,). Although some of these studies present their analyses for granular activated carbon (GAC), it has been found that differences in the processes to produce GAC and PAC have a minimal impact on the overall GHG emissions. The GHG emissions per ton GAC are therefore effectively the same as per ton of PAC (Novinda Market, 2012, US DOE, 2010). 


\section{ZSM-5 CATALYST}

ZSM-5 is an aluminosilicate zeolite. It is widely used in the petroleum industry as a heterogeneous catalyst, and it can also be used for catalyzing chemical reactions for biofuel production.

According to information in patent literature and limited publications (Stamires et al., 2007; Stockwell et al., 2005; Harris et al., 2004; Van Der Zon and Hilgers, 2008; Venuto and Habib, 1979), ZSM-5 composition can vary widely, and it is often combined with fillers and binders (e.g., silica gel and kaolin) when used as a catalyst. To differentiate neat ZSM-5 and the mixture of ZSM-5 with fillers and binders, we refer to the latter as ZSM-5 catalyst and the former as ZSM-5.

We used publicly available information to estimate ZSM-5 catalyst consumption rates in a generic biorefinery. A 60,000-barrel/day FCC unit processing a typical mixture of vacuum gas oils contains 450-500 tons of ZSM-5 catalyst (Kent, 2013). This loading converts to about 25-30 tons of catalyst in a biorefinery FCC, as proposed by Biddy and Jones (2013), that consumes 2,205 dry tons/day (2,000 metric tonne/day) of biomass and produces about 3,500 barrels/day of biofuel. Assuming a 2\% replacement rate for the catalyst (Kent, 2013; Pryor, 2014), the daily consumption of the catalyst is estimated to be 0.6 tons, or 1,200 lb. Recovery of spent ZSM-5 is generally considered economically infeasible and is not widely practiced (Bertolancini, 2014). Although details regarding the function of the zeolite, fillers, and binders are available (Venuto and Habib, 1979; Sadeghbeigi, 2000), the detailed formulation of ZSM-5 catalyst is difficult to obtain from specific catalyst manufacturers. Typically, a ZSM-5 catalyst contains at most 50 wt\% ZSM-5 (Stockwell et al., 2005; Harris et al., 2004; Stamires et al., 2007). On the basis of this information, we assume the ZSM-5 catalyst consists of 50\% ZSM-5, 25\% silica gel, and 25\% binder (kaolin).

\subsection{PREPARATION OF ZSM-5}

Figure 5 outlines the steps in the preparation of ZSM-5 catalyst (Lloyd 2011). Material flows in the production of ZSM-5 are listed in Table 15. The input materials listed in Table 15 are autoclaved for five days, then filtered and washed six times with hot deionized water. After that, the filter cake is blended with $\mathrm{SiO}_{2}$ gel and kaolin with sufficient water for spray drying. The final step is solids calcination (Argauer and Landolt, 1972; Mei et al., 2008; New Logic Research Inc., 2014). 


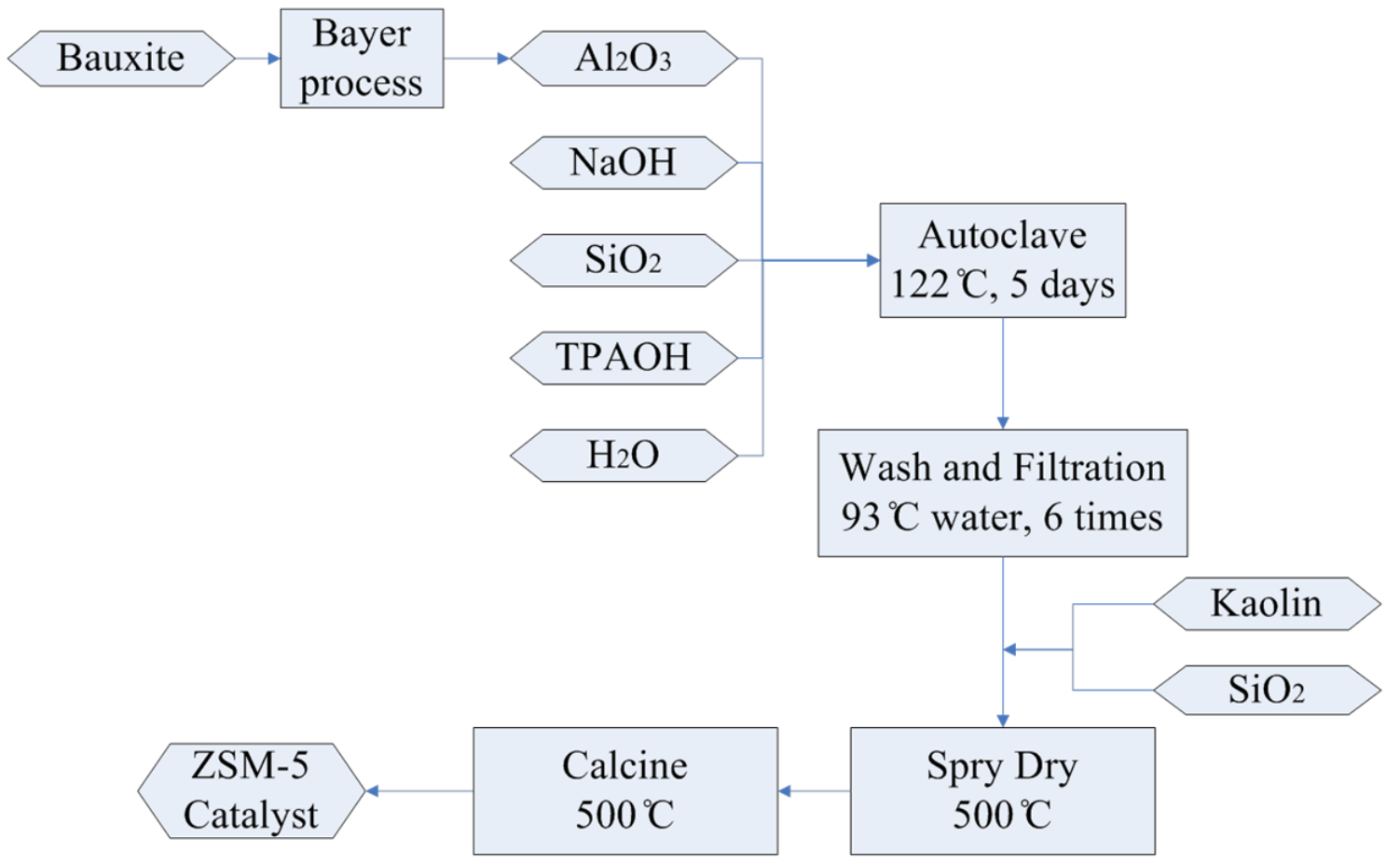

FIGURE 5 Diagram for preparation of ZSM-5 catalyst

Note: $\mathrm{TPAOH}=\mathrm{N}$-tetrapropylammonium hydroxide $\left[\left(\mathrm{CH}_{3} \mathrm{CH}_{2} \mathrm{CH}_{2}\right)_{4} \mathrm{~N}^{+} \mathrm{OH}^{-}\right]$

TABLE 15 Inputs and outputs for the production of 600 lb/day ZSM-5 (Argauer and Landolt, 1972)

\begin{tabular}{lr}
\hline \multicolumn{1}{c}{ Chemical } & $\begin{array}{c}\text { Amount } \\
(\mathrm{lb} / \text { day })\end{array}$ \\
\hline Inputs & \\
$\mathrm{TPAOH}$ & 588 \\
$\mathrm{NaOH}$ & 31 \\
$\gamma-\mathrm{Al}_{2} \mathrm{O}_{3}$ & 33 \\
$\mathrm{SiO}_{2}$ & 562 \\
$\mathrm{H}_{2} \mathrm{O}$ & 2,787 \\
Total & $\mathbf{4 , 0 0 0}$ \\
Outputs & \\
ZSM-5 $\left(\mathrm{Na}_{2} \mathrm{O} \cdot 2 \mathrm{Al}_{2} \mathrm{O}_{3} \cdot 65 \mathrm{SiO}_{2}\right)$ & 600 \\
\hline
\end{tabular}


Little data were available to support the calculation of the energy intensity of ZSM-5 production. To generate an estimate of this energy intensity, we used engineering calculations and calculated the energy consumed in each of the process steps. Table 16 shows the estimated energy consumption for each step and lists the assumptions used in the engineering calculations, in which process heat is assumed to be provided by steam produced from an $80 \%$ efficient natural gas boiler.

\section{TABLE 16 Energy consumption during ZSM-5 preparation}

\begin{tabular}{|c|c|c|c|}
\hline \multirow[b]{2}{*}{ Step } & \multicolumn{2}{|c|}{$\begin{array}{l}\text { Purchased Energy } \\
\text { Consumption (Btu) }\end{array}$} & \multirow[b]{2}{*}{ Bases for Engineering Calculations } \\
\hline & Natural Gas & Electricity & \\
\hline Autoclave & $1,900,000$ & - & $\begin{array}{l}4,000 \mathrm{lb} \text { of gel mixture is heated to } 122^{\circ} \mathrm{C} \text { for } \\
5 \text { days. We assumed heat loss is } 20 \% \text { per day. }\end{array}$ \\
\hline Wash and filtration & $4,200,000$ & 110,000 & $\begin{array}{l}4,000 \mathrm{lb} \text { of water is heated to } 93^{\circ} \mathrm{C} \text { and used to } \\
\text { wash solids six times. } 3.93 \mathrm{~kW} \text { are consumed } \\
\text { for } 8 \text { hours/day. }\end{array}$ \\
\hline Binder/filler & $5,200,000$ & - & $\begin{array}{l}\text { Binder and filler are heated and washed using } \\
\text { the same parameters for ZSM-5. }\end{array}$ \\
\hline Spray drying & $5,400,000$ & - & $\begin{array}{l}\text { A gel mixture (with } 65 \% \text { moisture content) is } \\
\text { dried with } 500^{\circ} \mathrm{C} \text { vent gas. The calculation } \\
\text { assumes } 10 \% \text { heat loss }\end{array}$ \\
\hline Calcining & $1,300,000$ & - & $\begin{array}{l}1,800 \mathrm{lb} \text { gel is heated from } 122^{\circ} \mathrm{C} \text { to } 500^{\circ} \mathrm{C} \text { at } \\
0.6 \mathrm{Btu} / \mathrm{lb}{ }^{\circ} \mathrm{F} \text {. The heat loss is } 40 \% \text {. }\end{array}$ \\
\hline Total & $18,000,000$ & 110,000 & For producing $600 \mathrm{lb}$ ZSM-5 \\
\hline $\begin{array}{l}\text { Total } \\
\text { (mmBtu/ton ZSM-5) }\end{array}$ & 60 & 0.36 & GREET inputs \\
\hline
\end{tabular}

Among the chemical inputs in Table 15, energy and material flows of $\gamma-\mathrm{Al}_{2} \mathrm{O}_{3}$ and $\mathrm{NaOH}$ are available in GREET. We developed new data to characterize the production of $\mathrm{SiO}_{2}$ gel. The first step in this process is sand extraction, with an energy consumption of $0.16 \mathrm{mmBtu}$ electricity/ton $\mathrm{SiO}_{2}$ (Boustead and Hancock, 1979). The sand is calcined with $\mathrm{Na}_{2} \mathrm{CO}_{3}$ to yield $\mathrm{Na}_{2} \mathrm{O} \cdot \mathrm{SiO}_{2}$ (Reaction 1), and then $\mathrm{H}_{2} \mathrm{SO}_{4}$ is added to form an aqueous salty solution containing silica colloids (Reaction 2). The $\mathrm{Na}_{2} \mathrm{SO}_{4}$ is rinsed away with water and the $\mathrm{SiO}_{2}$ gel is spray dried. The energy consumption for calcining, washing, and spray drying was estimated on the basis of process information from New Logic Research, Inc. (2014) to be $15.2 \mathrm{mmBtu}$ NG/ ton $\mathrm{SiO}_{2}$. Engineering calculation methods used to derive this estimate are the same as those in Table 16:

$$
\begin{aligned}
& \mathrm{SiO}_{2}+\mathrm{Na}_{2} \mathrm{CO}_{3} \rightarrow \mathrm{Na}_{2} \mathrm{O} \cdot \mathrm{SiO}_{2}+\mathrm{CO}_{2} \\
& \mathrm{Na}_{2} \mathrm{O} \cdot \mathrm{SiO}_{2}+\mathrm{H}_{2} \mathrm{SO}_{4} \rightarrow \mathrm{SiO}_{2}+\mathrm{H}_{2} \mathrm{O}+\mathrm{Na}_{2} \mathrm{SO}_{4}
\end{aligned}
$$


There is little information regarding the supply chain for TAPOH that can be used to construct the material and energy intensity of this compound. We estimated these parameters on the basis of the limited information in the literature and engineering calculations. The following reactions lead to the formation of TPAOH (Weston et al., 2003; Papa, 2000).

$$
\begin{array}{ll}
\mathrm{H}_{2} \mathrm{C}=\mathrm{CH}_{2}+\mathrm{CO}+\mathrm{H}_{2} \rightarrow \mathrm{CH}_{3} \mathrm{CH}_{2} \mathrm{CHO} & \Delta \mathrm{H}=-128.3 \mathrm{~kJ} / \mathrm{mol} \\
\mathrm{CH}_{3} \mathrm{CH}_{2} \mathrm{CHO}+\mathrm{H}_{2} \rightarrow \mathrm{CH}_{3} \mathrm{CH}_{2} \mathrm{CH}_{2} \mathrm{OH} & \Delta \mathrm{H}=-68.9 \mathrm{~kJ} / \mathrm{mol} \\
3 \mathrm{CH}_{3} \mathrm{CH}_{2} \mathrm{CH}_{2} \mathrm{OH}+\mathrm{PCl}_{3} \rightarrow 3 \mathrm{CH}_{3} \mathrm{CH}_{2} \mathrm{CH}_{2} \mathrm{Cl}+\mathrm{H}_{3} \mathrm{PO}_{3} & \Delta \mathrm{H}=-207.4 \mathrm{~kJ} / \mathrm{mol} \\
3 \mathrm{CH}_{3} \mathrm{CH}_{2} \mathrm{CH}_{2} \mathrm{OH}+\mathrm{NH}_{3} \rightarrow\left(\mathrm{CH}_{3} \mathrm{CH}_{2} \mathrm{CH}_{2}\right)_{3} \mathrm{~N}+3 \mathrm{H}_{2} \mathrm{O} & \Delta \mathrm{H}=-74.9 \mathrm{~kJ} / \mathrm{mol} \\
\left(\mathrm{CH}_{3} \mathrm{CH}_{2} \mathrm{CH}_{2}\right)_{3} \mathrm{~N}+\mathrm{CH}_{3} \mathrm{CH}_{2} \mathrm{CH}_{2} \mathrm{Cl} \rightarrow\left(\mathrm{CH}_{3} \mathrm{CH}_{2} \mathrm{CH}_{2}\right)_{4} \mathrm{~N}^{+} \mathrm{Cl}^{-} & \\
\left(\mathrm{CH}_{3} \mathrm{CH}_{2} \mathrm{CH}_{2}\right)_{4} \mathrm{~N}^{+} \mathrm{Cl}^{-}+\mathrm{NaOH} \rightarrow\left(\mathrm{CH}_{3} \mathrm{CH}_{2} \mathrm{CH}_{2}\right)_{4} \mathrm{~N}^{+} \mathrm{OH}^{-}+\mathrm{NaCl} &
\end{array}
$$

The overall TPAOH synthesis reaction is

$$
\begin{aligned}
& 4 \mathrm{H}_{2} \mathrm{C}=\mathrm{CH}_{2}+4 \mathrm{CO}+8 \mathrm{H}_{2}+\frac{1}{3} \mathrm{PCl}_{3}+\mathrm{NH}_{3}+\mathrm{NaOH} \rightarrow \\
& \left(\mathrm{CH}_{3} \mathrm{CH}_{2} \mathrm{CH}_{2}\right)_{4} \mathrm{~N}^{+} \mathrm{OH}^{-}+3 \mathrm{H}_{2} \mathrm{O}+\frac{1}{3} \mathrm{H}_{3} \mathrm{PO}_{3}+\mathrm{NaCl}
\end{aligned}
$$

It is difficult to estimate the energy consumption for Reactions 3-8. Calculating the heats of reaction for Reactions 3-6, however, reveals they are all exothermic (Perry and Green, 1997). We therefore assume no energy input is required for these reactions to proceed. We estimated the energy input for Reaction 7 on the basis of the work of Weston et al. (2003). It is assumed that to carry out Reaction 7 , the reactants are heated to $100^{\circ} \mathrm{C}$ for 32 hours with $40 \%$ heat loss. The resulting energy consumption is $0.43 \mathrm{mmBtu} / \mathrm{ton}$, which we assume to be provided by steam from an $80 \%$ efficient NG boiler. Reaction 8 is a reaction in solution and we assume it consumes no energy.

Among the reactants in the aggregated Reaction 9, energy and material flow for ethylene, $\mathrm{NH}_{3}$, and $\mathrm{NaOH}$ are all available in GREET. According to George (2000), CO is usually produced in syngas production, along with $\mathrm{H}_{2}$ and other gases. We assume NG-derived syngas provides the $\mathrm{CO}$ and $\mathrm{H}_{2}$ required in Reaction 9 (Dunn et al., 2014a).

We developed the material and energy intensity of $\mathrm{PCl}_{3}$ on the basis of information in Greenwood and Earnshaw (1997) and Threlfall (1951). This compound is prepared industrially by the reaction of chlorine, with a refluxing solution of white phosphorus in phosphorus trichloride. $\mathrm{PCl}_{3}$ is removed continuously from the reflux solution to avoid the formation of $\mathrm{PCl}_{5}$ (Greenwood and Earnshaw, 1997). White phosphorus $\left(\mathrm{P}_{4}\right)$ is produced by calcining phosphorous rock with sand and charcoal, as shown in Reaction 10 (Threlfall, 1951): 


$$
\begin{aligned}
& 2 \mathrm{Ca}_{3}\left(\mathrm{PO}_{4}\right)_{2}+6 \mathrm{SiO}_{2}+10 \mathrm{C} \rightarrow 6 \mathrm{CaSi}_{3} \mathrm{O}_{3}+10 \mathrm{CO}+\mathrm{P}_{4} \\
& \mathrm{P}_{4}+6 \mathrm{Cl}_{2} \rightarrow 4 \mathrm{PCl}_{3}
\end{aligned}
$$

Among the reactants in Reactions 10 and 11, energy and material flows of $\mathrm{Ca}_{3}\left(\mathrm{PO}_{4}\right)_{2}$, $\mathrm{C}$ (coke) and $\mathrm{Cl}_{2}$ exist in GREET. We have developed energy and material flows for $\mathrm{SiO}_{2}$ in this analysis. The calcining energy to produce $\mathrm{P}_{4}$ (Reaction 10) is assumed to be $2 \mathrm{mmBtu} / \mathrm{ton}$ reactant provided by an $80 \%$ efficient natural gas boiler (Dunn et al. 2014b). Reaction 11 is an exothermic reaction and we assume it consumes no energy. The aggregated material inputs for TPAOH production are shown in Table 17.

\section{TABLE 17 Material inputs for TPAOH production}

\begin{tabular}{lc}
\hline \multicolumn{1}{c}{ Inputs } & (ton/ton TPAOH) \\
\hline & \\
$\mathrm{C}_{2} \mathrm{H}_{4}$ & 0.55 \\
Syngas* & 1.15 \\
$\mathrm{NH}_{3}$ & 0.08 \\
$\mathrm{PCl}_{3}$ & 0.68 \\
$\mathrm{NaOH}$ & 0.59 \\
\hline * Contains 0.55 ton $\mathrm{CO}$ and 0.09 ton $\mathrm{H}_{2}$ per \\
\multicolumn{2}{l}{1.15 ton syngas. }
\end{tabular}

\subsection{PREPARATION OF FILLERS AND BINDERS}

The catalyst filler is $\mathrm{SiO}_{2}$ gel, for which we report material and energy intensity in Section 3.1. We model the energy and material flows in the production of the kaolin binder (Figure 6) on the basis of U.S. Patent 7,922,806 B2 (Yan et al., 2011). 


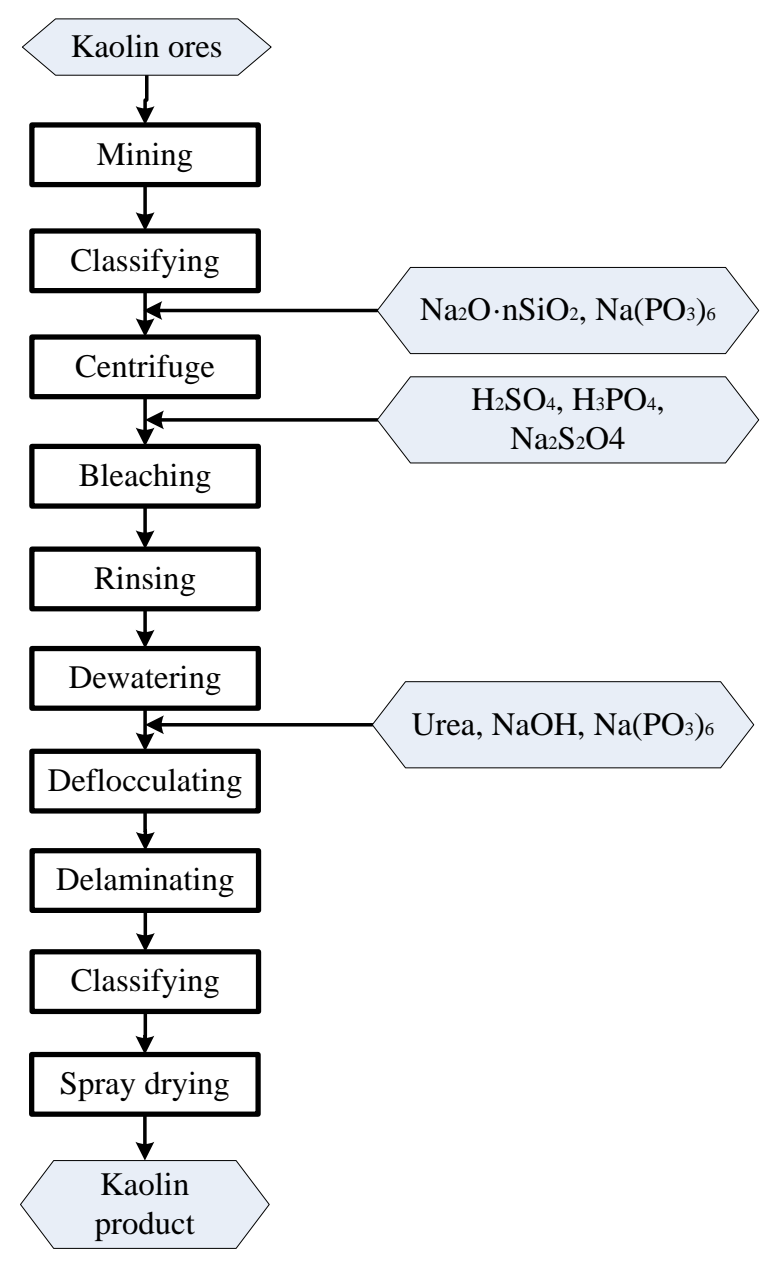

\section{FIGURE 6 Diagram for production of kaolin}

Energy and materials consumption for the production of kaolin are shown in Table 18 and Table 19, respectively. For the mining step, we assume that kaolin ore is as energy intensive to mine as olivine. Recall the energy intensity of olivine mining was estimated to be $2.3 \mathrm{mmBtu}$ diesel and $0.5 \mathrm{mmBtu}$ electricity per ton (Section 2.1). This energy intensity includes classifying to remove sand.

In the classifying step, sand is removed from kaolin with a horizontal spiral sedimentation centrifuge. We assume this stage is $90 \%$ efficient. We adopt the same efficiency for the subsequent centrifuge step. That is, we assume that $10 \%$ of the mass of kaolin entering these steps is not recovered. We turned to existing centrifuge and dewatering (with pressure filtration) energy consumption data in GREET's Algae Process Description (APD) to estimate the energy consumption of these steps as $8 \mathrm{kWh} / \mathrm{m}^{3}$ influent and $7.26 \mathrm{kWh} / \mathrm{m}^{3}$ influent, respectively (Frank et al., 2011). Stirring drives the energy use during bleaching, deflocculating, and delaminating. The energy consumption of homogenization $\left(36.7 \mathrm{kWh} / \mathrm{m}^{3}\right.$ processed volume $)$ is again adopted from the APD (Frank et al., 2011) to account for energy consumption of stirring. The energy consumption of rinsing is approximated with that for leaching (Dunn et al., 
2014b). Energy consumption of spray drying is estimated by applying the same method we used for this step of ZSM-5 production (Table 16). Taking into account kaolin losses at every stage, 1 dry ton of kaolin ore is consumed in the production of 0.87 dry ton of final kaolin product.

TABLE 18 Energy consumption during kaolin production

\begin{tabular}{lccc}
\hline \multirow{2}{*}{\multicolumn{1}{c}{ Step }} & \multicolumn{4}{c}{ Energy Consumption (mmBtu/ton kaolin) } \\
\cline { 2 - 4 } & NG & Electricity & Diesel \\
\hline \multirow{2}{*}{ Mining and classifying } & - & & \\
Centrifuge & - & 2.6 & 0.61 \\
Bleaching & - & 0.20 & - \\
Rinsing & - & 0.35 & - \\
Dewatering & - & 0.14 & - \\
Deflocculating & - & 0.07 & - \\
Delaminating & - & 0.20 & - \\
Spray drying & 1.9 & 0.20 & - \\
Total & 1.9 & - & 0.61 \\
\hline
\end{tabular}

TABLE 19 Materials inputs for kaolin production

\begin{tabular}{lr}
\hline \multicolumn{1}{c}{ Inputs } & ton/ton Kaolin \\
\hline & \\
$\left(\mathrm{NaPO}_{3}\right)_{6}$ & 0.038 \\
$\mathrm{H}_{2} \mathrm{SO}_{4}$ & 0.0062 \\
$\mathrm{Na}_{2} \mathrm{~S}_{2} \mathrm{O}_{4}$ & 0.019 \\
$\mathrm{H}_{3} \mathrm{PO}_{4}$ & 0.0062 \\
$\mathrm{NaOH}$ & 0.038 \\
$\mathrm{Urea}$ & 0.019 \\
$\mathrm{SiO}_{2}$ & 0.0076 \\
\hline
\end{tabular}

Of the material inputs in Table 19, GREET contains data for $\mathrm{H}_{2} \mathrm{SO} 4, \mathrm{H}_{3} \mathrm{PO}_{4}$, urea and $\mathrm{NaOH}$. This report develops material and energy flows for $\mathrm{SiO}_{2}$ (Section 3.1).

$\left(\mathrm{NaPO}_{3}\right)_{6}$ is not currently in GREET. We estimate its associated material and energy flows as follows, beginning with its synthesis in Reaction 12 through melting $\mathrm{NaH}_{2} \mathrm{PO}_{4}$ (EPA, 2000):

$$
6 \mathrm{NaH}_{2} \mathrm{PO}_{4} \rightarrow\left(\mathrm{NaPO}_{3}\right)_{6}+6 \mathrm{H}_{2} \mathrm{O}
$$


Because $\mathrm{NaH}_{2} \mathrm{PO}_{4}$ is chemically similar to $\mathrm{KH}_{2} \mathrm{PO}_{4}$, we adopt GREET data for the latter compound in this analysis. The energy for melting $\mathrm{NaH}_{2} \mathrm{PO}_{4}$ is assumed to be $2 \mathrm{mmBtu} / \mathrm{ton}$ reactant provided by an $80 \%$ efficient NG kiln (Dunn et al., 2014b).

We also needed to estimate new material and energy flow data for $\mathrm{Na}_{2} \mathrm{~S}_{2} \mathrm{O}_{4}$, which is produced through Reactions 13-15. First, sulfur is oxidized to produce $\mathrm{SO}_{2}$, and $\mathrm{NaHSO}_{3}$ is generated by reacting $\mathrm{SO}_{2}$ with $\mathrm{NaOH}$. Next, zinc dust is reacted with $\mathrm{NaHSO}_{3}$ to form $\mathrm{Na}_{2} \mathrm{~S}_{2} \mathrm{O}_{4}$ (OECD SIDS, 2004):

$\mathrm{S}+\mathrm{O}_{2} \rightarrow \mathrm{SO}_{2}$

$\mathrm{SO}_{2}+\mathrm{NaOH} \rightarrow \mathrm{NaHSO}_{3}$

$2 \mathrm{NaHSO}_{3}+\mathrm{Zn} \rightarrow \mathrm{Na}_{2} \mathrm{~S}_{2} \mathrm{O} 4+\mathrm{Zn}(\mathrm{OH})_{2}$

The aggregated reaction is:

$$
2 \mathrm{~S}+2 \mathrm{O}_{2}+2 \mathrm{NaOH}+\mathrm{Zn} \rightarrow \mathrm{Na}_{2} \mathrm{~S}_{2} \mathrm{O} 4+\mathrm{Zn}(\mathrm{OH})_{2}
$$

As discussed previously, sulfur is produced industrially as a co-product or waste of petroleum products and natural gas production and considered burden free (Johnson et al., 2013). The energy and material flow of $\mathrm{NaOH}$ and $\mathrm{Zn}$ is available in GREET. The calcining energy for Reaction 15 is assumed to be $2 \mathrm{mmBtu} /$ ton reactants (Dunn et al., 2014b). This energy is assumed to be provided by NG with an efficiency of $80 \%$. 


\section{SUMMARY}

Table 20 summarizes the fossil fuel use consumption and GHG emissions for the seven compounds included in the GREET catalyst module. It is important to note that limited data necessitated reliance on engineering calculations and estimates to generate these results. ZSM-5 and Mo/Co/ $\gamma-\mathrm{Al}_{2} \mathrm{O}_{3}$ catalysts have the greatest cradle-to-gate $\mathrm{GHG}$ emissions. However, when coal-based activated carbon is used to produce the alcohol synthesis catalyst, the cradle-togate GHG emissions are 9 million $\mathrm{g} \mathrm{CO}_{2} \mathrm{e}$ per ton of catalyst, the greatest of any catalyst included in the module. One important contributor to these $\mathrm{CO}_{2}$ emissions is non-combustion emissions from carbon burn-off in the carbonization step of the process $\left(8\right.$ million $\mathrm{g} \mathrm{CO}_{2} \mathrm{e} / \mathrm{ton}$ activated carbon). In the case of the ZSM-5 catalyst, the GHG emissions are dominated by the production of ZSM-5 (Figure 7). The contribution of ZSM-5 production to cradle-to-gate GHG emissions is one order of magnitude higher than that from kaolin and $\mathrm{SiO}_{2}$ gel as filler.

Emissions associated with the energy consumed during ZSM-5 production contribute the most to overall ZSM-5 production emissions. Production of TPAOH and $\mathrm{SiO}_{2}$ gel also contribute significantly. In the case of $\mathrm{Mo} / \mathrm{Co} / \gamma-\mathrm{Al}_{2} \mathrm{O}_{3}$ catalysts, the $\mathrm{GHG}$ emissions are dominated by the production of $\gamma$-alumina and ammonium molybdate (Figure 8).

To assess the sensitivity of results to changes in the cradle-to-gate GHG intensity of the inputs to ZSM-5 catalysts, we conducted a sensitivity analysis, varying these intensities individually by $\pm 25 \%$. It is important to note that the values that were varied in this analysis were the cradle-to-gate value for each input. For example, the value for kaolin incorporates the full fuel-cycle GHG emissions of the NG consumed in kaolin production and the GHGs emitted over the full supply chain of the urea consumed in producing kaolin. This variation in input GHG intensity resulted in at most a 9\% change in the GHG intensity of the ZSM-5 catalyst. This catalyst's GHG intensity was most sensitive to the GHG intensity of TPAOH production. It was slightly less sensitive to the GHG intensity of the ZSM-5 production process and $\mathrm{SiO}_{2}$ gel production, and relatively insensitive to the GHG intensity of kaolin production.

One important addition to the catalyst module is the option for a user to build a userdefined catalyst. Users can choose from any of the 45 materials included in the module as inputs and need to enter the energy consumed in and non-combustion emissions from the catalyst preparation process.

As the catalyst module is refined, we will continue to seek improved data for key drivers of catalyst cradle-to-gate emissions. We have commenced estimating impacts associated with the handling, treatment, and disposal of wastes generated in catalyst production and use. Very little information is available on how spent bioprocessing catalysts may be treated and/or whether metals would be recovered from them. We will continue to investigate these aspects of the catalyst life cycle and refine the module to address them. 
TABLE 20 Fossil fuel use and GHG emissions of the compounds in the GREET catalyst module

\begin{tabular}{|c|c|c|c|c|c|c|c|c|}
\hline $\begin{array}{l}\text { Cradle-to- } \\
\text { Gate Result }\end{array}$ & $\begin{array}{c}\text { Alcohol } \\
\text { Synthesis } \\
\text { Catalyst } \\
\text { (wood- } \\
\text { derived } \\
\text { activated } \\
\text { carbon) }\end{array}$ & $\begin{array}{l}\text { Alcohol } \\
\text { Synthesis } \\
\text { Catalyst } \\
\text { (coal- } \\
\text { derived } \\
\text { activated } \\
\text { carbon) }\end{array}$ & DEPG & Olivine & $\begin{array}{c}\text { Tar } \\
\text { Reforming } \\
\text { Catalyst }\end{array}$ & $\begin{array}{l}\text { ZSM-5 } \\
\text { Catalyst }\end{array}$ & $\begin{array}{c}\mathrm{Mo} / \mathrm{Co} \\
\gamma \mathrm{Al}_{2} \mathrm{O}_{3} \\
\text { Catalyst } \\
\end{array}$ & $\mathrm{Pt} / \mathrm{yAl}_{2} \mathrm{O}_{3}$ \\
\hline $\begin{array}{l}\text { Fossil fuels } \\
\text { (mmBtu/ton) }\end{array}$ & 50 & 50 & 57 & 5.3 & 19 & 100 & 111 & 78 \\
\hline $\begin{array}{l}\mathrm{GHG} * 10^{-6} \\
\left(\mathrm{~g} \mathrm{CO}_{2} \mathrm{e} / \text { ton }\right)\end{array}$ & 4 & 9 & 3 & 0.5 & 6 & 7 & 8 & 6 \\
\hline
\end{tabular}

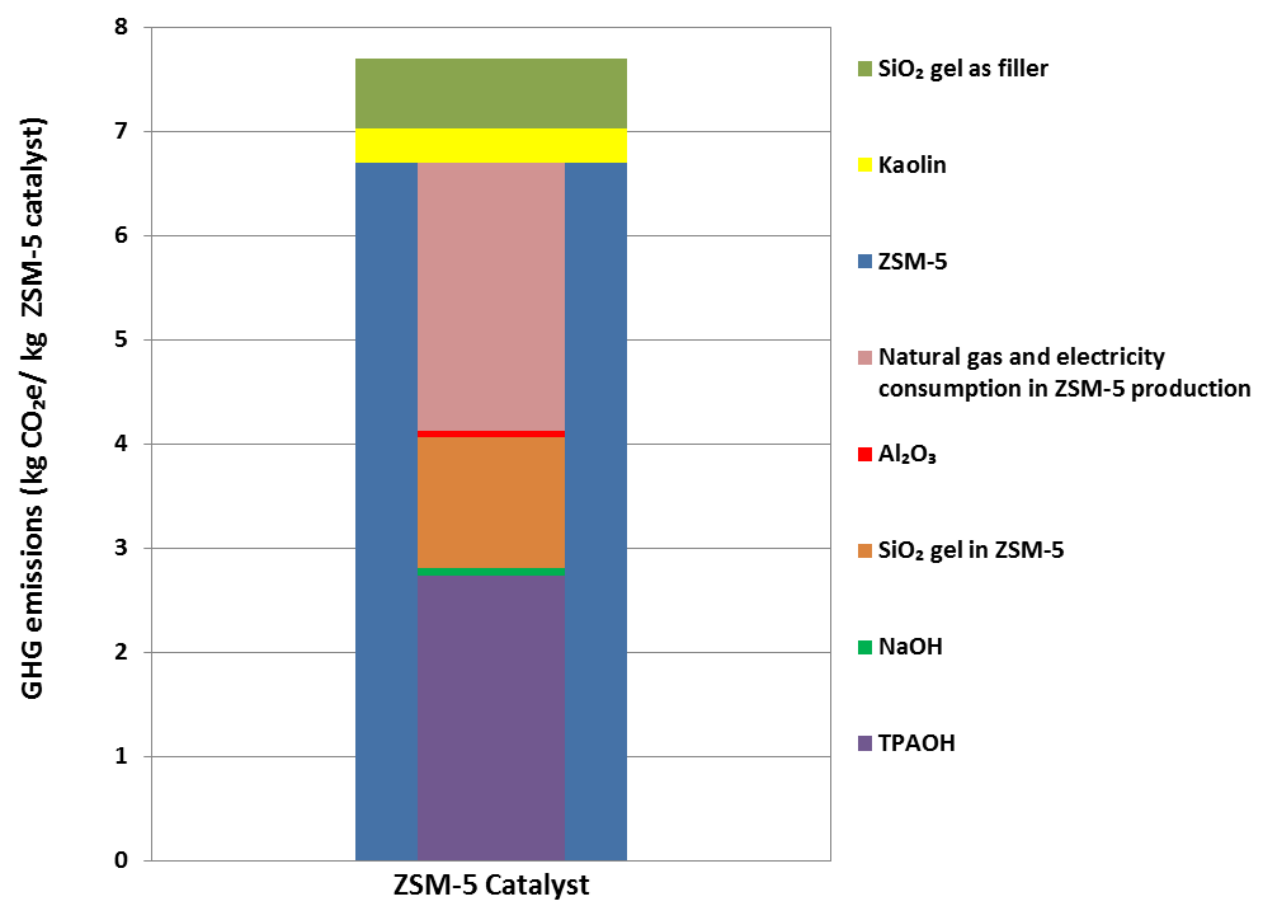

FIGURE 7 Cradle-to-gate GHG emissions for ZSM-5 catalyst; emissions from ZSM-5 are broken up into five contributing factors 


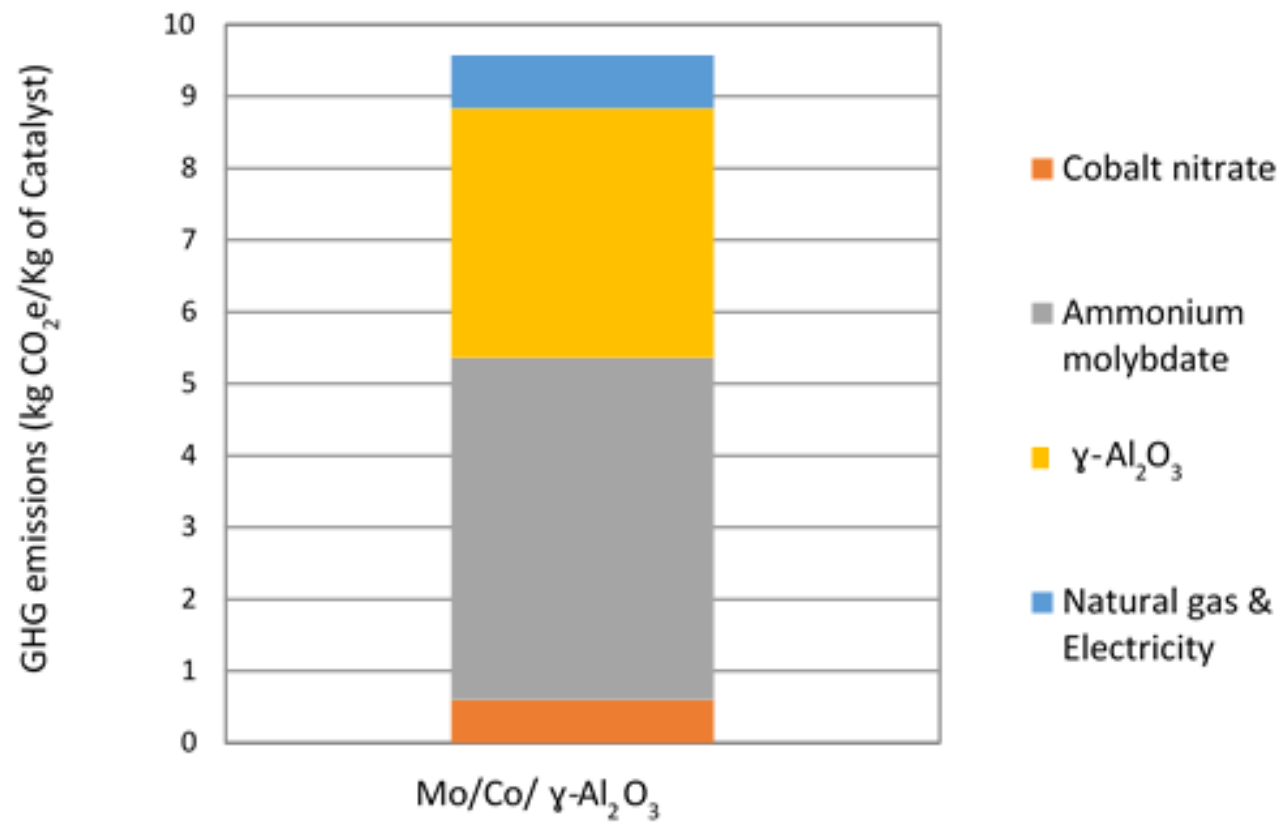

FIGURE 8 Cradle-to-gate GHG emissions for $\mathrm{Mo} / \mathrm{Co} / \mathrm{y}$-Alumina catalyst

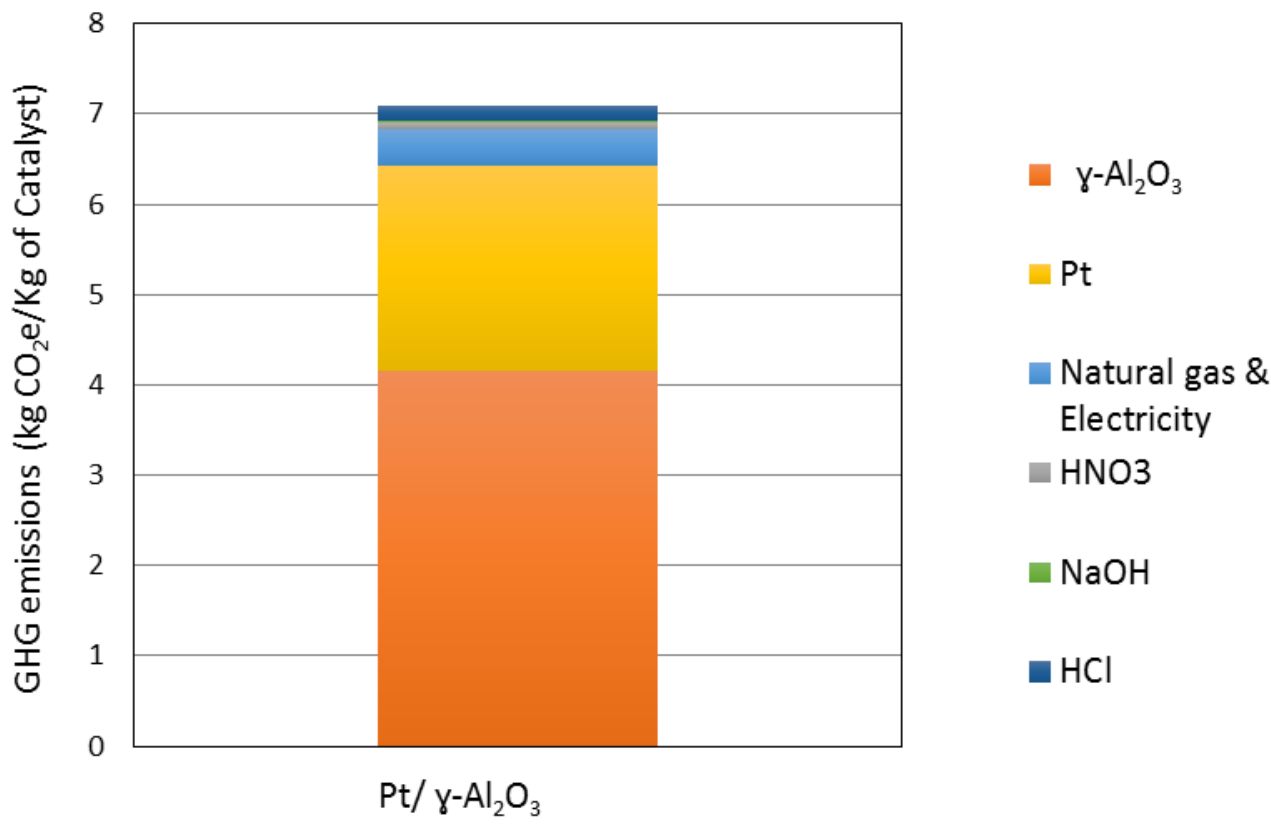

FIGURE 9 Cradle-to-gate GHG emissions for Pt/y-Alumina catalyst 


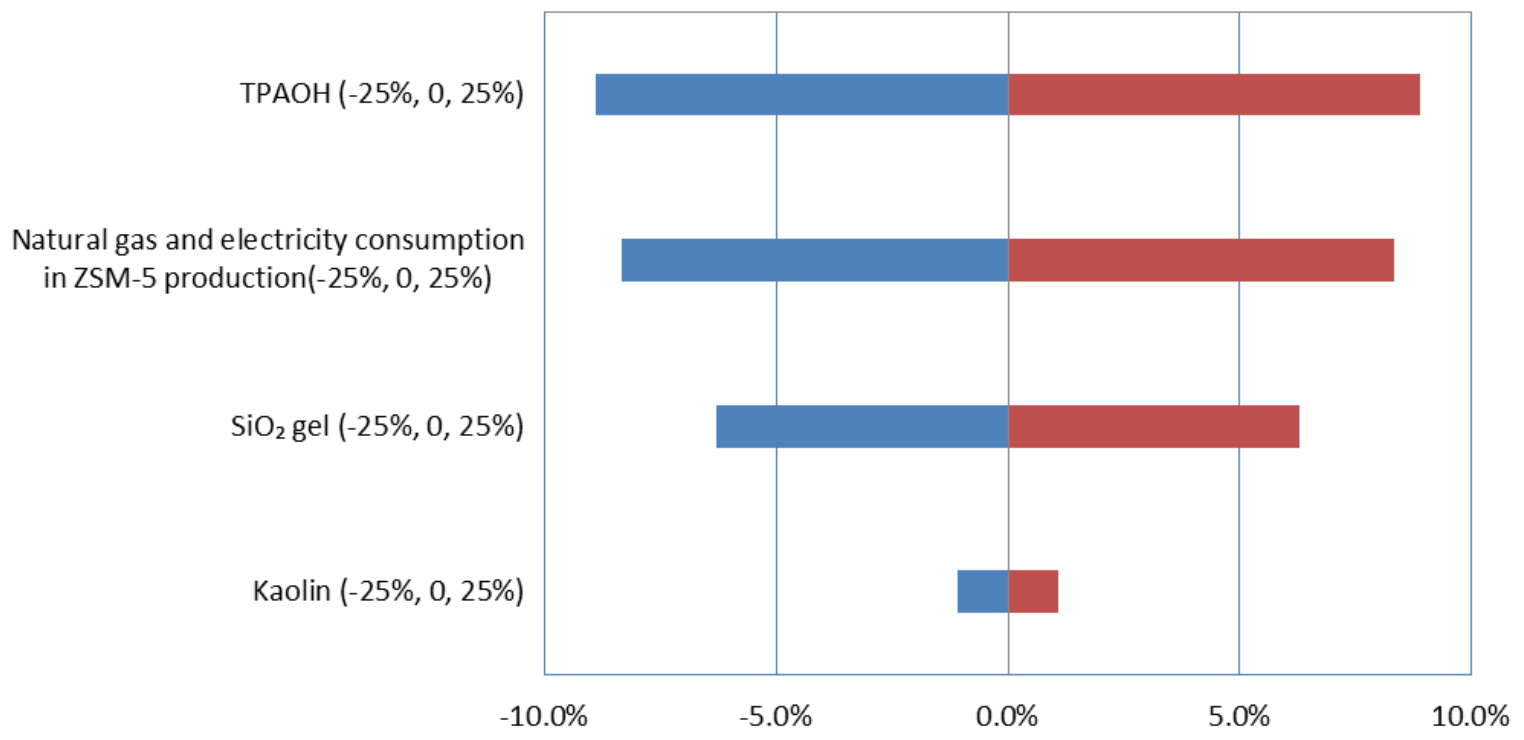

FIGURE 10 Sensitivity analysis of ZSM-5 catalyst cradle-to-gate GHG emissions; baseline value is $7.7 \mathrm{~kg} \mathrm{CO} 2 \mathrm{e} / \mathrm{kg} \mathrm{ZSM-5} \mathrm{catalyst}$ 


\section{REFERENCES}

All, M. F., A. Bukhari, and M. Saleem. Ind. Eng. Chem. Prod. Res. Dev. 22 no. 4 (1983): 691694.

Alonso, D. M., S. G. Wettstein, and J. A. Dumesic. "Bimetallic catalysts for upgrading of biomass to fuels and chemicals," Chemical Society Reviews 41 no. 24 (2012): 7965-8216.

Appell, H. R. US Patent 2830877, issued 1958.

Argauer, R. J., and G. R. Landolt. Crystalline Zeolite ZSM-5 and Method of Preparing the Same. US Patent 3,702,886 A, issued November 14, 1972.

Baker, F. S., C. E. Miller, A. J. Repik, and E. D. Tolles. “Carbon, Activated.” In Kirk-Othmer Encyclopedia of Chemical Technology, 2003.

Barbooti, M.M. Amer. J. Anal. Chem. 6 (2015): 325-333.

Barakat, M. A., and M. H. H. Mahmound. Hydrometallurgy 72 (2004): 179-184.

Bayer, P., E. Heuer, U. Karl, and M. Finkel. "Economical and Ecological Comparison of Granular Activated Carbon (GAC) Adsorber Refill Strategies," Water Research 39 (2005): 17191728.

Bertolacini, R. Personal communication from D.C. Cronauer, Argonne National Laboratory, to R. Bertolacini, Argonne National Laboratory, on May 14, 2014.

Benavides, P. T., Q. Dai, J. Sullivan, J. C. Kelly, and J. Dunn. Material and Energy Flows Associated with Select Metals in GREET2: Molybdenum, Platinum, Zinc, Nickel, Silicon. ANL/ESD-15/11, Argonne National Laboratory, 2015.

Benson, M., C. R. Bennett, J. E. Harry, M. K. Patel, and M. Cross. Resources, Conservation and Recycling 31 (2000):1-7.

Bernardis, F.L., R. A Grant, and D. C. Sherrington. Reactive \& Functional Polymers 65 (2005): 205.

Biddy, M., and S. Jones. Catalytic Upgrading of Sugars to Hydrocarbons Technology Pathway. NREL/TP-5100-58055, PNNL-22319, May 2013.

Boustead, I., and F. Hancock. Handbook of Industrial Energy Analysis. Ellis Horwood, Ltd., 1979.

Burnham, A., M. Wang, and Y. Wu. Development and Applications of GREET 2.7 - The Transportation Vehicle-Cycle Model. ANL/ESD/ 06-5, Argonne National Laboratory, 2006. 
Cabot Norit Americas, Inc. Evaluation of Permit Application. Pryor, Oklahoma: Oklahoma Department of Environmental Quality - Air Quality Division, 2014.

Camara, E. O. G., K. Sakota, and B. Oppenberg. CEH Marketing Research Report: Activated Carbon. SRI International, 1999.

Camara, E. G., T. Kalin, and Y. Inoguchi. :CEH Marketing Research Reports - Activated Carbon.” In United States, Western Europe, \& Japan: Chemical Economics Handbook. SRI Consulting, 2010.

Caterpillar. Caterpillar Performance Handbook, 44th edition. Peoria, IL, U.S.: Caterpillar, 2014.

Dai, Q., A. Burnham, A. Elgowainy, and J. C. Kelly. Life Cycle Assessment Update of Aluminum Production and Semi-fabrication for GREET Model. ANL/ESD-15/12, Argonne National Laboratory, 2015.

De Aberasturi, D. J., R. Pinedo, I. R. de Larramendi, J. I. R. de Larramendi, and T. Rojo. Minerals Engr. 24 (2011): 505-513.

Dunn, J.B., F. Adom, N. Sather, J. Han, and S. Snyder. Life-Cycle Analysis of Bioproducts and Their Conventional Counterparts in GREET. ANL/ESD-14/9, Argonne National Laboratory, Argonne, IL, 2014a.

Dunn, J. B., L. Gaines, M. Barnes, J. Sullivan, and M. Wang. Material and Energy Flows in the Materials Production, Assembly, and End-of-Life Stages of the Automotive Lithium-Ion Battery Life Cycle. ANL/ESD/12-3 Rev., Argonne National Laboratory, Argonne, IL, June 2014b. Available at https://greet.es.anl.gov/publication-lib-lca.

Dutta, A., M. Talmadge, J. Hensley, M. Worley, D. Dudgeon, D. Barton, P. Groenendijk, D. Ferrari, B. Stears, E. M. Searcy, C. T. Wright, and J. R. Hess. Process for Design and Economics for Conversion of Lignocellulosic Biomass to Ethanol Thermochemical Pathway by Indirect Gasification and Mixed Alcohol Synthesis. NREL/TP-5100-51400, National Renewable Energy Laboratory, Golden, CO, May 2011. Available at http://www.nrel.gov/biomass/pdfs/51400.pdf.

European Commission. 2010. Executive summary of the reference document on best available techniques in the cement, lime and magnesium oxide manufacturing industries. Available at http://eippcb.jrc.ec.europa.eu/reference/BREF/clm_bref_0510.pdf.

EPA. 2000. Sodium Phosphate Listing Background Document for the Inorganic Chemical Listing Determination. U.S. Environmental Protection Agency (EPA), Washington D.C. Available at http://www.epa.gov/osw/hazard/wastetypes/wasteid/inorchem/docs/sod-phos.pdf.

Frank, E., J. Han, I. Palou-Rivera, A. Elgowainy, and M. Wang. User Manual for Algae LCA with GREET: Version 0.0. ANL/ESD/11-7, Argonne National Laboratory, Argonne, IL, 2011. Available at http://greet.es.anl.gov/publications. 
Franklin Associates. Cradle-to-Gate Life Cycle Inventory of Nine Plastic Resins and Four Polyurethane Precursors. Prepared for the Plastics Division of the American Chemistry Council, 2011.

George, C. "Carbon Monoxide," in Kirk-Othmer Encyclopedia of Chemical Technology, John Wiley \& Sons, Inc., 2000.

GMC Global Mining Crusher. "Jaw crusher fuel tank capacity and fuel consumption.” GMC Global Mining Crusher, accessed 2015, http://amei.in/mill2010/17663/jaw-crusher-fuelconsumption.html.

Greenwood, N. N., and A. Earnshaw. Chemistry of the Elements ( $2^{\text {nd }}$ ed.). ButterworthHeinemann, 1997.

Grover, P., and S. Mishra. Biomass Briquetting: Technology and Practices. Bangkok: Food and Agriculture Organization of the United Nations, 1996. Available at http://www.fao.org/docrep/006/ad579e/ad579e00.pdf

Grube, H. "Hexachloroplatinic (IV) Acid," in Handbook of Preparative Inorganic Chemistry, Volume 2, 2nd Ed., edited by G. Brauer, 1569. New York: Academic Press, 1963.

Harris, D. H., M. Xu, D. Stockwell, and R. J. Madon. FCC Catalysts for Feeds Containing Nickel and Vanadium. US Patent 6,673,235 B2, issued January 6, 2004.

He, K. "A Calculation of the Environmental Footprint of a Granular Activated Carbon Regeneration Facility." Environmental Footprint of Regenerating GAC, 2012. Available at http://nature.berkeley.edu/classes/es196/projects/2012final/HeK_2012.pdf.

Johnson, M. C., I. Palou-Rivera, and E. D. Frank. "Energy Consumption During the Manufacture of Nutrients for Algae Cultivation." Algal Research 2 no. 4 (2013): 426-436. Available at http://www.sciencedirect.com/science/article/pii/S2211926413000854.

Jackson, S. D., J. Willis, G. D. McLellan, G. Webb, M. B. T. Keegan, R. B. Moyes, S. Simpson, P. B.Wells, and R. Whyman. "Supported Metal Catalysts: Preparation, Characterization, and Function: I. Preparation and Physical Characterization of Platinum Catalysts." J. Catal. 139 (1993): 191.

Johnson, T.P., and D. E. Deegan. "The Environmental Impact of Plasma-based Smelting of Spent Catalysts for Precious Metal Recovery." Proceedings of the Shechtman International Symposium, 2014.

Kauffman, George B. “Ammonium Hexachloroplatinate (IV).” Inorganic Syntheses 9 (1967): 182-185. doi:10.1002/9780470132401.ch51.

Kecojevlc, V., and D. Komljenovic. "Haul truck fuel consumption and $\mathrm{CO}_{2}$ emissions under various engine load conditions.” Mining Engineering 62 no. 12 (2010): 44-48. 
Kent, J. A. Handbook of Industrial Chemistry and Biotechnology, Vol. 1, pp. 727-728. Springer, 2013.

Kim, C. H., S. I. Woo, and S. H. Jeon. "Recovery of Platinum Group Metals from Recycled Automotive Catalytic Converters by Carbochlorination." Ind. Eng. Chem. Res. 39 (2000): 11851192.

Kramer, D. A. “Current Mining of Olivine and Serpentine," U.S. Geological Survey, 2001. Available at http://www.netl.doe.gov/publications/proceedings/01/minecarb/kramer.pdf.

Llanos, Z. R., G. F. Provoost, W. G. Deering, and F. J. Debaene. Integrated process for the recovery of metals and fused alumina from spent catalysts. US Patent 5702500, issued December 30, 1997.

Lloyd, L. Handbook of Industrial Catalysts. New York: Springer, 2011.

Long, F. M., and W. H. Sawyer. Process for preparing a heavy crude conversion catalyst. US Patent 3,989,645, issued November 2, 1976.

Magrini-Bair, K. A., S. Czernik, R. French, Y. O. Parent, E. Chornet, D. C. Dayton, C. Feik, and R. Bain. "Fluidizable Reforming Catalyst Development for Conditioning Biomass-derived Syngas." Applied Catalysis A: General 318 no. 20 (2007): 199-206.

Marsh, H., and F. Rodríguez Reinoso. Activated Carbon. Oxford, U.K: Elsevier, 2006.

McDougall, G. "The Physical Nature and Manufacture of Activated Carbon." Journal of the South African Institute of Mining and Metallurgy 91 (1991): 109-120.

Mei, C., P. Wen, Z. Liu, H. Liu, Y. Wang, W. Yang, Z. Xie, W. Hua, and Z. Gao. "Selective Production of Propylene from Methanol: Mesoporosity Development in High Silica HZSM-5." Journal of Catalysis 258 no. 1 (2008): 243-249.

Mitsche, R.T. and G. N. Pope. Method of preparation of alumina catalyst support or carrier material. US Patent 4,098,874, issued July 4, 1978.

New Logic Research, Inc. "Membrane Filtration of Colloidal Silica Study: A Cost-Effective and Efficient Solution." 2014. Available at http://www.vsep.com/pdf/ColloidalSilica.pdf.

Novinda Market. "Life Cycle Assessment of Greenhouse Gases for the Product: Amended Silicates." 2012. Available at http://www.novinda.com/files/Final_Amended_Silicates_Life_Cycle_Assessment.pdf.

Oasmaa, A., E. Leppamaki, P. Koponen, J. Lavandeer, and E. Topola. "Physical characterization of biomass-based pyrolysis liquids." VTT Publications 306, Technical Research Centre of Finland, ESPOO, 1997. 
OECD SIDS (Organization for Economic Cooperation and Development, Screening Information Data Set). "Sodium Dithionite." SIDS Initial Assessment Report for SIAM 19, Berlin, Germany, October 19-22, 2004.

Papa, A. J. "Propanal," in Ullmann's Encyclopedia of Industrial Chemistry. John Wiley and Sons, 2000. DOI:10.1002/14356007.a22_157.pub2.

Perry, R. H., and D. W. Green. Perry's Chemical Engineers' Handbook. New York: McGrawHill, 1997.

Pomarede, V., "Recycling of spent oil catalysts: Gulf Chemical and Metallurgical Corporation process for metals recovery," 247 $7^{\text {th }}$ ACS Nat. Mtg. \& Exposition, Dallas, TX, March 19, 2014.

Pryor, N. Personal communication from D. C. Cronauer, Argonne National Laboratory, to N. Pryor, W. R. Grace \& Company, on May 21, 2014.

Reactor Resources. "Reactor Resources - The New Standard in Sulfiding." Available at http://www.reactor-resources.com/performance-products/alumina-overview, last accessed August 2, 2015.

Richardson, H. W. "Cobalt Compounds," in Kirk-Othmer Encyclopedia of Chemical Technology, John Wiley \& Sons, Inc., 2000.

RitchieSpecs. “Caterpillar 789C Rock Truck.” Available at http://www.ritchiespecs.com/specification?type=Con\&category=Rock+Truck\&make=Caterpillar \&model=789C \&modelid=93276.

Sadeghbeigi, R. Fluid Catalytic Cracking Handbook: Design, Operation, and Troubleshooting of FCC Facilities. Gulf Professional Publishing, 2000.

Saffaria, S. "A LCA Study of Activated Carbon Adsorption and Incineration in Air Pollution Control.” Master's Thesis, University of Boras, School of Engineering, Sweden, 2009.

Satterfield, C. N. Heterogeneous Catalysis in Industrial Practice, $2^{\text {nd }}$ ed. New York: McGrawHill, Inc., 1991.

Spieker, W. A., and J. R. Regalbuto. "A fundamental model of platinum impregnation onto alumina.” Chem. Engr. Science 56 (2001): 3491-3504.

Srinivasachar, S., S. Benson, C. Crocker, and J. Mackenzie. System and method for coproduction of activated carbon and steam/electricity. US Patent 20090317320 A1, issued December 24, 2009. 
Stamires, D., P. O’Connor, G. Pearson, and W. Jones. Crystal Structured Bauxite Containing Adjuvants Selected from Alkaline Earth, Transition or Noble Metals, Actinides, Gallium, Boron, Phosphorus, Silicon, Metal Oxides, Hydroxides, Clays, Zeolites, Spinels, Perovskites, Organic and Inorganic Acids and Salts and/or Mixtures, Used as Hydroreforming Catalyst. U.S. Patent 7,208,446 B2, issued April 24, 2007.

Stevens, R. R. Process for Producing Alcohols from Synthesis Gas. US Patent 4882360 A, issued November 21, 1989.

Stiefel, E. I. "Molybdenum Compounds," in Kirk-Othmer Encyclopedia of Chemical Technology, John Wiley \& Sons, Inc., 2000.

Stockwell, D. M., S. H. Brown, and J. Y. Ryu. Structurally Enhanced Cracking Catalysts. US Patent 6,942,784 B2, issued September 13, 2005.

Threlfall, R. E. 100 Years of Phosphorus Making: 1851-1951. Oldbury: Albright and Wilson, Ltd., 1951.

Twigg-Smith, C., S. Buda, and F. Peyer. Permit Application Review: 1,500 TPH Portable Crushing and Screening Plant. Kohanaiki, Kona, Hawaii, 2004. Available at http://yosemite.epa.gov/R9/air/EPSS.NSF/6924c72e5ea10d5e882561b100685e04/cb77e781ce6c 91500a256ec400776be7/\$FILE/Proposed.CTS\%20Earthmoving.0562-01-CT\%20Review.pdf

U.S. Department of Energy. "Energy and Environmental Profile of the U.S. Mining Industry: Coal.” Washington, D.C., 2013. Available at http://energy.gov/sites/prod/files/2013/11/f4/coal.pdf.

U.S. Department of Energy (U.S. DOE). Environmental Assessment for Department of Energy Loan Guarantee to Red River Environmental Products, LLC for Construction and Start-up of an Activated Carbon Manufacturing Facility in Red River Parish, Louisiana. U.S. Department of Energy, Loan Guarantee Program Office, Washington, D.C., June 2010.

U.S. Environmental Protection Agency. EPA Coalbed Methane Outreach Program Technical Options Series:Use of Coal Mine Methane in Coal Dryers. Washington, DC: U.S Environmental Protection Agency, 1998.

Van Der Zon, M., and J. H. Hilgers. Spray Drying an Aqueous Slurry of a Zeolite, Clay, and Poly Aluminum Chloride, Calcining to Produce a Fluid Catalytic Cracking Catalyst. US Patent 7,442,664 B2, issued October 28, 2008.

Venuto, P.B., E.T. Habib, and M. Dekker. Fluid catalytic cracking with zeolite catalysts, New York, (1979): 156.

Wang Z., J. B. Dunn, J. Han, Wang. Material and Energy Flows in the Production of Cellulosic Feedstocks for Biofuels for GREET1_2013. Report ANL/ESD/13-9, Argonne National Laboratory, October 2013. Available at http://greet.es.anl.gov/publication-lib-lca. 
Wang, Z., J. B. Dunn, J. Han, and M. Q. Wang. "Effects of co-produced biochar on life cycle greenhouse gas emissions of pyrolysis-derived renewable fuels." Biofuels, Bioproducts and Biorefining, 8 no. 2 (2014): 189-204.

Wabash Power Equipment Company. "The Source for Mills \& Pulverizers.” 2013. Available at http://wabashpower.com/mills-brochure.pdf.

Weston, C. W., J. R. Papcun, and M. Dery. "Ammonium Compounds," in Kirk-Othmer Encyclopedia of Chemical Technology, John Wiley and Sons, 2003.

Yan, C., X. Zhu, J. Chen, S. Hai, J. Xu, X. Chen, Y. Cui, and W. Zeng. Process for Producing Kaolin Product for Paper Coating. US Patent 7,922,806 B2, issued Apr. 12, 2011. 



\section{Argonne}

\section{Energy Systems Division}

9700 South Cass Avenue, Bldg. 362

Argonne, IL 60439-4815

www.anl.gov 